Acta Protozool. (2017) 56: 255-281

www.ejournals.eu/Acta-Protozoologica

doi:10.4467/16890027AP.17.023.7825

PROTOZOOLOGICA

\title{
Constraints on Phylogenetic Interrelationships among Four Free-living Litostomatean Lineages Inferred from 18S rRNA gene-ITS Region sequences and Secondary Structure of the ITS2 molecule
}

\author{
Lubomír RAJTER, Peter VĎAČNÝ \\ Comenius University in Bratislava, Department of Zoology, Bratislava, Slovakia
}

\begin{abstract}
We investigated interrelationships between four free-living litostomatean lineages, using 18S rRNA gene and ITS region sequences as well as the secondary structure of the ITS2 molecules. Our phylogenetic analyses confirmed the deep split of free-living litostomateans into Rhynchostomatia and Haptoria represented here by Haptorida, Pleurostomatida, and Spathidiida. This bifurcation is also corroborated by the signature of the rhynchostomatian and haptorian ITS2 molecules. Specifically, the consensus stems of helices II and III are longer by one base pair in Rhynchostomatia, while the terminal loops of both helices are longer by one or two nucleotide/-s in Haptoria. A close relationship of Pleurostomatida and Haptorida is favored by quartet likelihood-mapping and supported by a 5'-AG vs. CU-3' motif in the variable part of helix II and by two morphological apomorphies, i.e., meridionally extending somatic kineties and a non-three-rowed dorsal brush. Although monophyletic origin of Spathidiida is poorly supported in phylogenetic trees, the unique motif 5'-GA vs. UC-3' present in the consensus helix II stem could be an important molecular synapomorphy of spathidiids, apart from the ancestrally anteriorly curved somatic kineties and the three-rowed dorsal brush. The peculiar family Pseudoholophryidae has very likely found its phylogenetic home among spathidiids, as an early branching lineage.
\end{abstract}

Key words: dorsal brush, Haptoria, molecular synapomorphies, morphological evolution, Pseudoholophryidae, Rhynchostomatia

\section{INTRODUCTION}

Free-living ciliates of the class Litostomatea Small and Lynn, 1981 represent apex predators in microbial food webs both in aquatic and terrestrial habitats (Foissner et al. 1995, 1999, 2002; Lynn 2008). They are morphologically well adapted to the raptorial lifestyle by having toxicysts (also known as extrusomes)

Address for correspondence: Peter Vd'ačný, Department of Zoology, Faculty of Natural Sciences, Comenius University in Bratislava, Ilkovičova 6, 84215 Bratislava, Slovak Republic; E-mail: peter. vdacny@uniba.sk that are used to seize other protists and microscopic metazoans. Over 400 free-living litostomatean species have been described from a variety of habitats all around the globe (e.g., Kahl 1930a, 1930b, 1931; Foissner et al. 1995, 1999, 2002; Kreutz and Foissner 2006; Foissner and Xu 2007; Lin et al. 2009; Vd'ačný and Foissner 2012; Foissner 2016). According to Vd'ačný et al. (2011a), they are classified in two subclasses, the Rhynchostomatia Jankowski, 1980 and the Haptoria Corliss, 1974. The former subclass is characterized by a prominent proboscis and a ventrally located cytostome, and includes two orders, the Tracheliida Vd'ačný et al., 2011b and the Dileptida Jankowski, 1978. The 
latter subclass contains five well-defined groups: (i) the order Pleurostomatida Schewiakoff, 1896 with laterally flattened body and ventrally extending, slit-like cytostome; (ii) the order Didiniida Jankowski, 1978 with barrel-shaped to globular body carrying an anterior oral cone; (iii) the order Lacrymariida Lipscomb and Riordan, 1990 with teardrop-shaped cell whose anterior part is differentiated into a head-like structure; (iv) the order Spathidiida Foissner and Foissner, 1988 with cylindroidal to spatulate body equipped with a typically three-rowed dorsal brush; and finally (v) the order Haptorida Corliss, 1974 with bursiform body and usually two-rowed brush. However, there are some free-living genera (e.g., Chaenea Quennerstedt, 1867; Helicoprorodon Fauré-Fremiet, 1950; Homalozoon Stokes, 1890; Mesodinium Stein, 1863; and Trachelotractus Foissner, 1997) whose systematic position remains enigmatic, mainly because of the long-branch artifacts in $18 \mathrm{~S}$ rRNA gene trees and/or because of phylogenetic uninformativness of their 18S rRNA gene (Johnson et al. 2004; Vd'ačný et al. 2011a; Kwon et al. 2014; Vd’ačný and Rataj 2017).

The majority of recent phylogenetic studies focused mainly on the internal evolutionary relationships within the subclass Rhynchostomatia (Vd'ačný et al. 2011b, 2017; Vd'ačný and Foissner 2012; Jang et al. 2014; Vd'ačný and Rajter 2015), the order Pleurostomatida (Lin et al. 2007, 2008; Gao et al. 2008; Pan et al. 2010, 2013; Vd'ačný et al. 2015; Wu et al. 2015, 2016), and the orders Spathidiida and Haptorida (Vd'ačný et al. 2011a, 2012, 2014; Vd'ačný and Foissner 2013; Jang et al. 2015, 2017; Rajter and Vd’ačný 2016). In spite of the great effort and considerable increase in taxon sampling during the last decade, phylogenetic relationships among these main monophyletic groups have been left almost unresolved. To cast more light onto this problem, in this study we have not only further increased the taxon and marker sampling, but we have also utilized phylogenetic information contained in the secondary structure of the litostomatean ITS2 molecules.

Thus, with the considerably increased dataset and complex phylogenetic approach, we obtained a possibility to constrain evolutionary kinships between four main monophyletic free-living litostomatean lineages: Rhynchostomatia, Pleurostomatida, Haptorida and Spathidiida. Specifically, we tested: (i) the sister group relationship between rhynchostomatians and the three haptorian orders; (ii) the phylogenetic closeness of the orders Haptorida and Pleurostomatida; and (iii) the monophyly of the peculiar family Pseudoholophy- ridae Berger et al., 1984 as redefined by Rajter and Vd'ačný (2016) as well as its spathidiid phylogenetic home. Our rationale for these hypotheses was based on the following assumptions. The Rhynchostomatia have maintained the most plesiomorphic morphology among all litostomateans (i.e., ventrally located cytostome, preoral kineties corresponding to adoral organelles, and formation of anarchic fields during stomatogenesis) and therefore might be the best candidate for a sister group of the three haptorian orders studied. Members of the order Haptorida display some pleurostomatid (i.e., meridionally extending somatic kineties and reduced number of dorsal brush rows) as well as some spathidiid features (i.e., bursiform body and anteriorly localized oral bulge opening). Since somatic ciliary structures are supposed to be phylogenetically more conserved than oral ones (Lynn 2008), haptorids might be more closely related to pleurostomatids than to spathidiids. Recently, we have recognized that the genus Pseudoholophrya Berger et al., 1984 clusters within the order Spathidiida (Rajter and Vd'ačný 2016), which was a rather surprising result because Pseudoholophrya does not appear as a typical spathidiid. In the present study, we have obtained 18S rRNA gene as well as ITS region sequences from a morphologically closely related genus, Paraenchelys Foissner, 1983, which enabled us to test the monophyly of the family Pseudoholophryidae as well as its spathidiid phylogenetic home. Finally, we have carefully analyzed whether the secondary structure of the ITS2 molecule bears information about phylogenetic interrelationships among free-living litostomateans and searched for molecular signatures in the ITS2 region that could address the segregation of the four main free-living litostomatean lineages studied.

\section{MATERIALS AND METHODS}

\section{Sampling and sample processing}

All newly sequenced species were collected in the Palearctic and the Nearctic realm from various terrestrial and semi-terrestrial habitats, except for a single pleurostomatid species, Litonotus crystallinus, which was isolated from a freshwater habitat (for details, see Supplementary Table S1). The non-flooded Petri dish method (Foissner et al. 2002) was used to cultivate soil and moss ciliates, while the freshwater species was directly investigated after transportation of the aquatic sample to the laboratory.

Isolated specimens were studied in detail under an optical microscope Leica DM2500 at low (50-400 $\times)$ and high $(1000 \times$, 
oil immersion) magnifications, using bright field and differential interference contrast optics. A special attention was paid to taxonomically important features of litostomatean ciliates, as described by Rajter and Vd'ačný (2016). Species identification was performed according to the following studies: Kahl (1930a, 1930b, 1931), Foissner (1984, 1987), Foissner and Al-Rasheid (2007), Foissner and Xu (2007), Gabilondo and Foissner (2009), and Jang et al. (2017).

\section{Molecular methods}

After taxonomic identification, several specimens were picked from each isolated litostomatean species/population using a micropipette. Obtained specimens were washed several times to remove contaminants and were directly transferred into the ATL tissue lyses buffer. Subsequently, their genomic DNA was extracted with the DNeasy Tissue Kit (Qiagen, Hildesheim, Germany).

For the purposes of this study, we amplified two molecular markers, the $18 \mathrm{~S}$ rRNA gene with the universal eukaryotic primers designed by Medlin et al. (1988) and the ITS1-5.8S-ITS2 region with the forward primer ITS-F designed by Miao et al. (2008) and the reverse primer LO-R designed by Pawlowski (2000). Polymerase chain reaction (PCR) included $5 \mu$ of the extracted template DNA, $0.4 \mu \mathrm{l}$ of each primer $(10 \mathrm{pmol} / \mu \mathrm{l})$, and $10 \mu \mathrm{l}$ of the multiplex PCR buffer (PCR multiplex Kit, Qiagen, Hildesheim, Germany). The final volume was adjusted to $20 \mu \mathrm{l}$ with deionized distilled water. PCR conditions and quality check of the amplified DNA were performed according to Vd'ačný et al. (2011a, 2012). Finally, the resulting PCR products were purified using the NucleoSpin Gel and PCR clean-up Kit (Macherey-Nagel, Düren, Germany).

The purified DNA fragments were cloned into a plasmid vector using the pGEM ${ }^{\circledR}-\mathrm{T}$ and the pGEM ${ }^{\circledR}-\mathrm{T}$ Easy Vector Systems (Promega, Fitchburg, Wisconsin, United States). After 12-hour incubation of ligation mixtures, the created recombinant plasmids were introduced into the host organism Escherichia coli (strain JM109). Screening for clones with the desired DNA inserts was performed with the blue-white selection. The recombinant plasmids were isolated from the host bacteria using the extraction kit PureYield ${ }^{\mathrm{TM}}$ Plasmid Miniprep System (Promega, Fitchburg, Wisconsin, United States) and sequenced on an ABI 3730 automatic sequencer (Macrogen, Amsterdam, The Netherlands), using the universal M13 forward and reverse primers.

\section{Phylogenetic methods}

The obtained sequences were imported into Chromas ver. 2.33 (Technelysium Pty Ltd.) to check their quality. Subsequently, the desired DNA sequences were trimmed at the 5' and 3' ends and assembled into contigs using BioEdit ver. 7.2.5 (Hall 1999). Alignments of the trimmed DNA sequences were constructed on the GUIDANCE2 server (http://guidance.tau.ac.il/ver2/), using the MAFFT algorithm and 100 bootstrap repeats (Sela et al. 2015). Multiple alignments were generated for each marker: six 18S rRNA gene, six ITS region and two concatenated datasets (for details, see Supplementary Table S2). Analyzed alignments included up to 64 free-living litostomatean taxa, for 56 of which both 18S rRNA gene and ITS region sequences were available. Trees were computed as unrooted and a posteriori were rooted with the midpoint method implemented in FigTree ver. 1.2.3 (Andrew Rambaut, available at http://tree.bio.ed.ac.uk/software/figtree/).
The best evolutionary substitution models for maximum likelihood and Bayesian analyses were selected using jModelTest ver. 0.1.1 under the Akaike information criterion (Guindon and Gascuel 2003; Posada 2008). Maximum likelihood analyses were performed on the PhyML ver. 3.0 server (http://www.atgc-montpellier.fr/ phyml/) (Guindon et al. 2010), with SPR tree-rearrangement and 1,000 non-parametric bootstrap replicates. Bayesian analyses were conducted in the program MrBayes on XSEDE ver. 3.2.6 (Miller et al. 2010) on the CIPRES portal ver. 3.1 (http://www.phylo.org). Bayesian inferences were performed with four chains running simultaneously for $5,000,000$ generations and every 1000th tree being sampled. The first $25 \%$ of the sampled trees were considered as burn-in and discarded prior tree reconstruction. Consequently, a $50 \%$ majority rule consensus of the remaining trees was computed and posterior probabilities of its branching pattern were estimated. For bootstrap values, we consider values $<70$ as low, 70-94 as moderate, and $\geq 95$ as high following Hillis and Bull (1993). For Bayesian posterior probabilities, we consider values $<0.94$ as low, and $\geq 0.95$ as high following Alfaro et al. (2003).

A super-network approach was applied to incorporate information from multiple alignments and trees as well as to depict their topological incongruence. A super-network was calculated from 80 randomly selected post-burn-in trees from the Bayesian inference of the 18S-A-D, ITSR-C and ITSR-D as well as the CON-1 and $\mathrm{CON}-2$ alignments, i.e., 10 trees were randomly chosen from the posterior distribution of the Bayesian MCMC analyses of each of the eight alignments. The super-network was constructed in SplitsTree4 ver. 4.12.8 (Huson 1998), using the Z-closure option, tree size weighted mean, ten runs, and the refined heuristic technique (Huson et al. 2004).

To avoid problems connected with uneven taxon sampling of the four main free-living litostomatean lineages studied, phylogenetic interrelationships among them were examined with the likelihood-mapping method as implemented in the program Tree-Puzzle ver. 5.0 (Schmidt et al. 2002). This analysis was conducted on the $18 \mathrm{~S}-\mathrm{A}$ and CON-1 alignments, whereby the program was employed to estimate transition/transversion parameters, nucleotide frequencies, and rate heterogeneity of the alignments (Strimmer and von Haeseler 1997). To assess the support of an internal branch of the tested datasets, all possible quartets were calculated. For further details, see Vd'ačný et al. (2014) and Vd'ačný (2017).

Predictions of the putative secondary structure of the litostomatean ITS2 molecules were performed using the free-energy minimization approach on the Mfold webserver ver. 3.0 (http://unafold.rna. albany.edu/?q=mfold/RNA-FoldingForm) (Zuker 2003). All folded ITS2 sequences showed the "ring model" with a similar pairing pattern in helices II and III. Helix I was, however, present only in some taxa and its positional homology was ambiguous. Therefore we constructed consensus secondary structures only for the phylogenetically conserved helices II and III in several higher litostomatean taxonomic groups on the Alifold webserver (http://rna.tbi. univie.ac.at/cgi-bin/RNAalifold.cgi) with default options (Bernhart et al. 2008; Gruber et al. 2008). Moreover, the base frequencies at each position and mutual information of the base-paired regions in helices II and III were calculated in the web program RNALogo (http://rnalogo.mbc.nctu.edu.tw) (Chang et al. 2008). The number of conserved base pairs and unpaired bases in bulges and loops were counted for each structural domain of the individual litostomatean ITS2 molecules as predicted on the Mfold webserver. 


\section{RESULTS}

\section{Phylogenetic analyses}

In this study, we obtained five new 18S rRNA gene sequences and ten new ITS1-5.8S-ITS2 region sequences of free-living litostomateans from the orders Haptorida, Pleurostomatida and Spathidiida. Their length, GC content, and GenBank accession numbers were summarized, jointly with other sequences utilized in our phylogenetic analyses, in Supplementary Table S1. In total, we computed four $18 \mathrm{~S}$ rRNA gene trees from the 18S-A alignment (Fig. 1) and the 18S-B-D alignments (data not shown), four ITS1-5.8S-ITS2 region trees from the ITSR-A dataset (Fig. 2) and the ITSR-B-D datasets (data not shown) as well as two 18S-ITS region trees from the CON-1 (Fig. 3) and the CON-2 alignment (data not shown). To incorporate information from all alignments and multiple trees, we constructed a super-network (Fig. 4).

On the basis of the midpoint rooting method, there was a deep bifurcation of the class Litostomatea into two main lineages, corresponding to the subclass Rhynchostomatia and the subclass Haptoria, in all 18S rRNA gene and concatenated 18S-ITS region trees. Monophyletic origin of each subclass was fully or highly statistically supported in both Bayesian and maximum likelihood phylogenies. Within the Rhynchostomatia, the orders Tracheliida and Dileptida were uncovered with full or high statistical support only in $18 \mathrm{~S}$ rRNA gene and concatenated 18S-ITS region trees. The branching pattern within the order Dileptida was congruent with results of our previous phylogenetic studies (Vd'ačný et al. 2011b, 2017; Jang et al. 2014; Vd'ačný and Rajter 2015). The family Dileptidae was, however, revealed to be monophyletic with high statistical support only in Bayesian trees inferred from the concatenated datasets, while the family Dimacrocaryonidae was depicted monophyletic with full or high support in all 18S rRNA gene and 18S-ITS region trees.

Within the subclass Haptoria, three main phylogenetic lineages, corresponding to the orders Pleurostomatida, Haptorida and Spathidiida, were recognized. (i) Monophyly of the order Pleurostomatida was corroborated with full statistical support in all alignments and by all algorithms used, except for the ITS1-5.8S-ITS2 region trees, where the peculiar Protolitonotus magnus was placed in a basal polytomy of the subclass Hapto- ria. As expected, new sequences from Litonotus crystallinus and L. muscorum were placed in the family Litonotidae, together with related taxa from the genus Loxophyllum (Figs 1-4). (ii) Monophyly of the order Haptorida was also fully statistically supported by the $18 \mathrm{~S}$ rRNA gene, whereby the new $18 \mathrm{~S}$ rRNA sequence from Fuscheriides sp. clustered together with Fuscheria terricola and Fuscheria sp. (Figs 1-4). Fuscheria nodosa was placed in a basal polytomy of the subclass Haptoria in the ITS1-5.8S-ITS2 trees, while this species was depicted in a sister position to the order Pleurostomatida in the 18S-ITS trees with low statistical support. (iii) The order Spathidiida was distinguished only in 18S rRNA gene and concatenated 18S-ITS Bayesian trees, but statistical support for its monophyletic origin was low. Phylogenetic positions of Arcuospathidium cultriforme scalpriforme, Spathidium amphoriforme pop. $1, S$. claviforme and S. terricola, as inferred from the newly added ITS region sequences in the ITS and concatenated 18S-ITS datasets, were basically congruent with previous ITS and concatenated 18S-ITS trees, respectively (Rajter and Vd'ačný 2016; Jang et al. 2017). The newly sequenced American population of Apobryophyllum schmidingeri (represented here by clones 1 and 2) clustered together with German and Korean populations of that species in a highly/fully statistically supported clade (Figs 1-3). Paraenchelys terricola was usually nested in the spathidiid cluster in the vicinity of Pseudoholophrya terricola and Acaryophrya sp., but monophyletic origin of this clade was either poorly statistically supported or was left unsupported. Nevertheless, all three taxa formed the most distinct split within the order Spathidiida in the super-network based on multiple post burn-in Bayesian trees (Fig. 4).

All four main free-living litostomatean lineages were also clearly recognizable in the super-network based on 80 randomly selected post-burn-in trees from the Bayesian inference of eight alignments (Fig. 4). Interrelationships among these lineages were comparable with those found in the present $50 \%$ majority rule consensus trees (Figs 1-3). However, the super-network also revealed two conflicting relationships: the order Pleurostomatida is either a sister group of the Haptorida or of the Spathidiida. To test these hypotheses, we performed quartet likelihood-mapping which favored the sister-group relationship between Pleurostomatida and Haptorida by $52.2 \%$ of data points for the $18 \mathrm{~S}-\mathrm{A}$ alignment and by $71.3 \%$ of data points for the CON-1 dataset (Fig. 5). 
18S rRNA gene

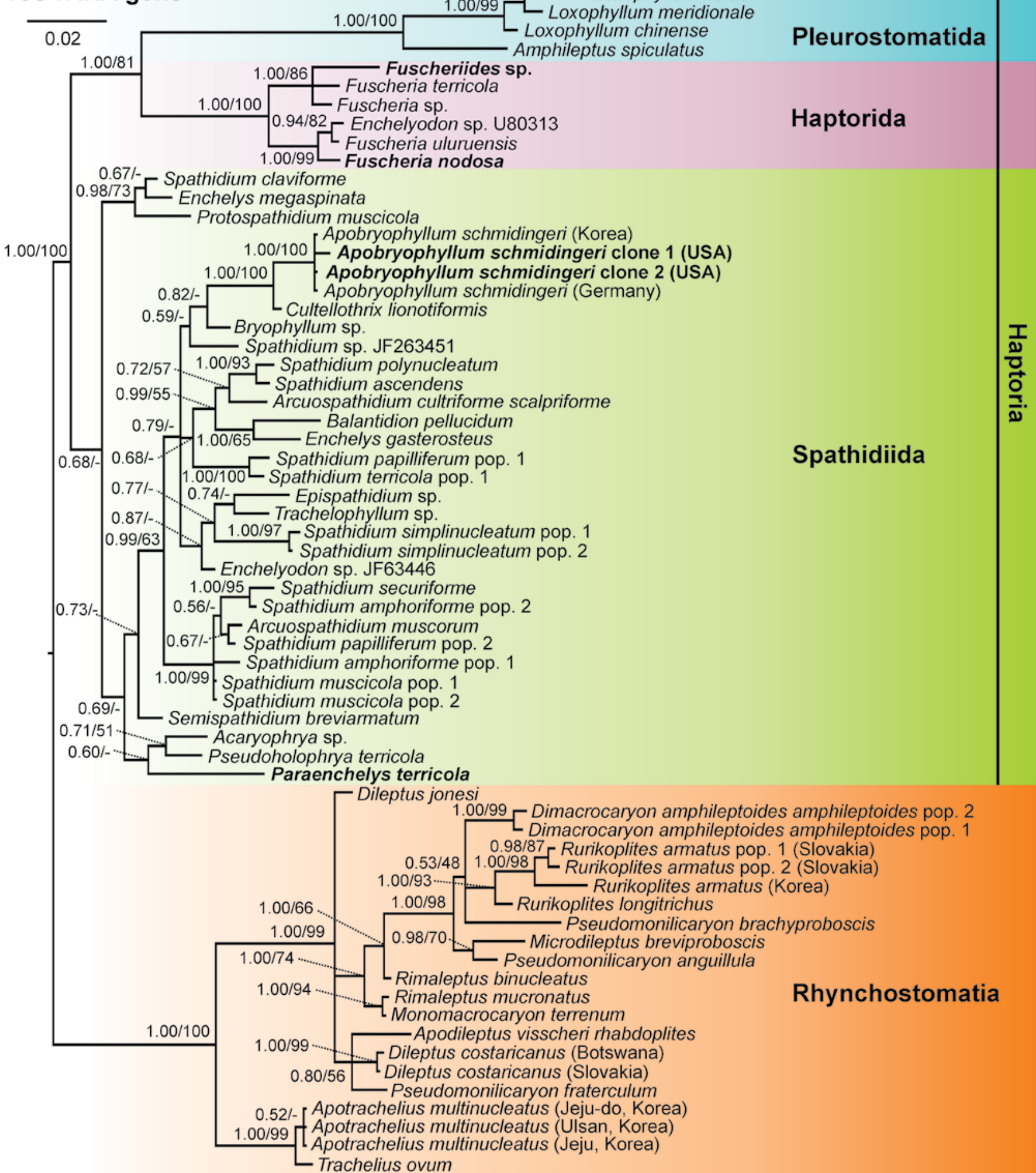

Fig. 1. Phylogeny based on the 18S rRNA gene of 64 free-living litostomatean taxa (alignment 18S-A). Posterior probabilities for Bayesian inference and bootstrap values for maximum likelihood were mapped onto the $50 \%$ majority rule Bayesian consensus tree. Dashes indicate ML bootstrap values below 50\%. Sequences in bold were obtained during this study. The scale bar indicates two substitutions per one hundred nucleotide positions. For details on taxa, evolutionary model used, and characteristics of the 18S-A alignment, see Supplementary Table S1 and S2. 


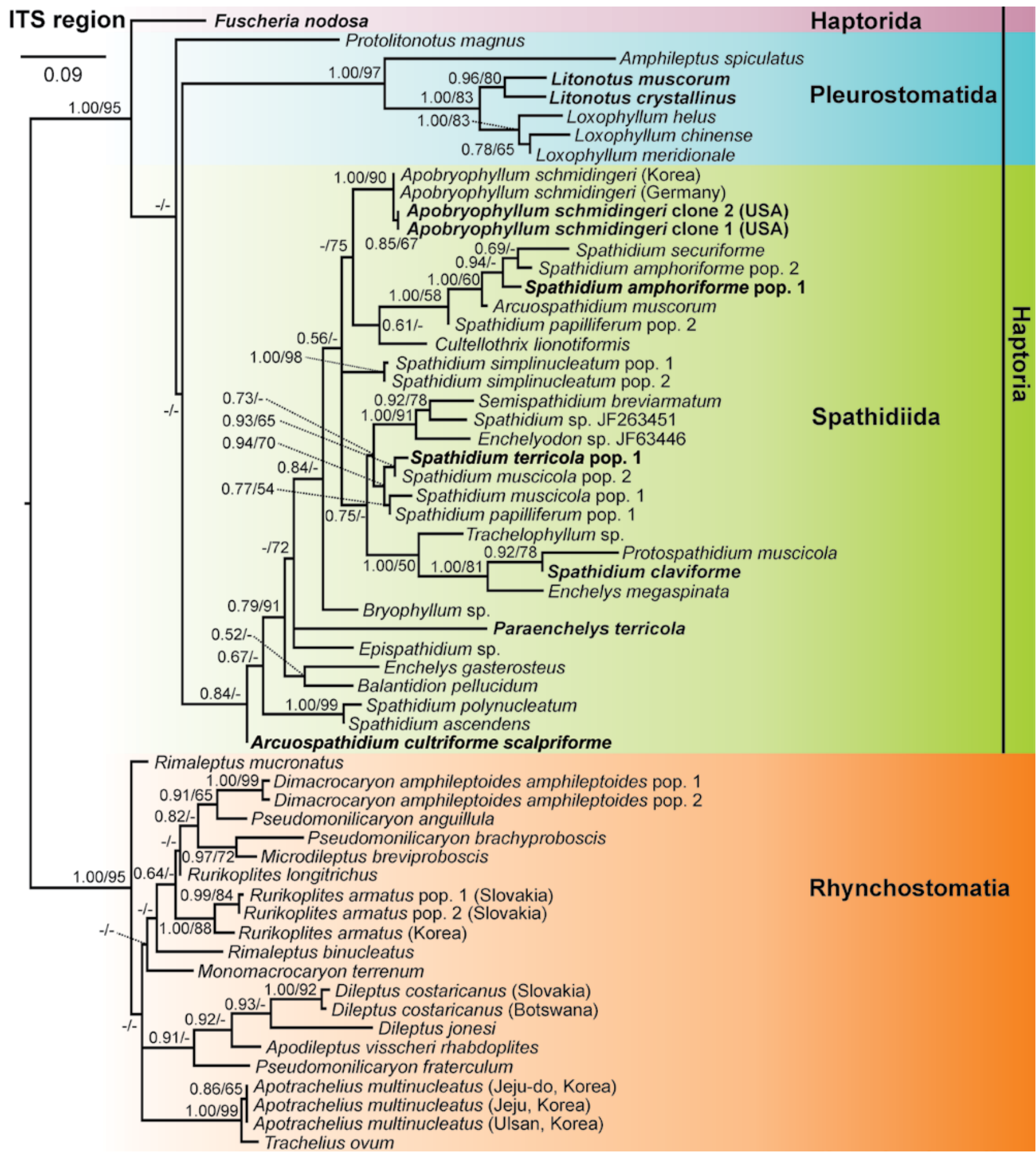

Fig. 2. Phylogeny based on the ITS1-5.8S-ITS2 region of 60 free-living litostomatean taxa (alignment ITSR-A). Posterior probabilities for Bayesian inference and bootstrap values for maximum likelihood were mapped onto the best ML tree. Dashes indicate posterior probabilities below 0.50 and ML bootstrap values below 50\%. Sequences in bold were obtained during this study. The scale bar indicates nine substitutions per one hundred nucleotide positions. For details on taxa, evolutionary model used, and characteristics of the ITSR-A alignment, see Supplementary Table S1 and S2. 


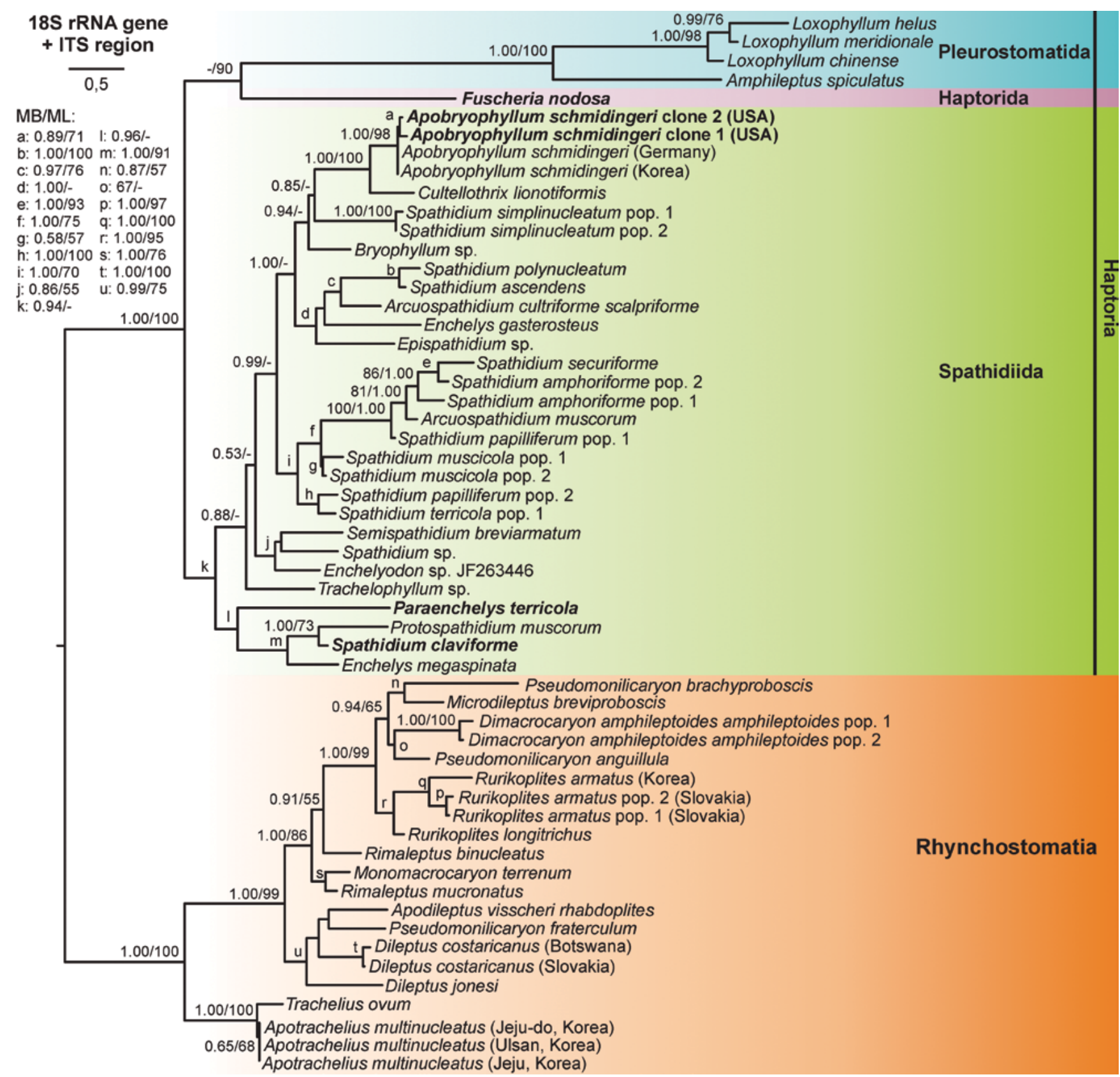

Fig. 3. Phylogeny based on the $18 \mathrm{~S}$ rRNA gene and the ITS1-5.8S-ITS2 region of 56 free-living litostomatean taxa (alignment CON-1). Posterior probabilities for the Bayesian inference and bootstrap values for maximum likelihood were mapped onto the $50 \%$ majority rule ML tree. Dashes indicate posterior probabilities below 0.50 and ML bootstrap values below 50\%. The scale bar indicates five substitutions per ten nucleotide positions. For details on taxa, evolutionary model used, and characteristics of the CON-1 alignment, see Supplementary Table S1 and S2. 


\section{Supernetwork}

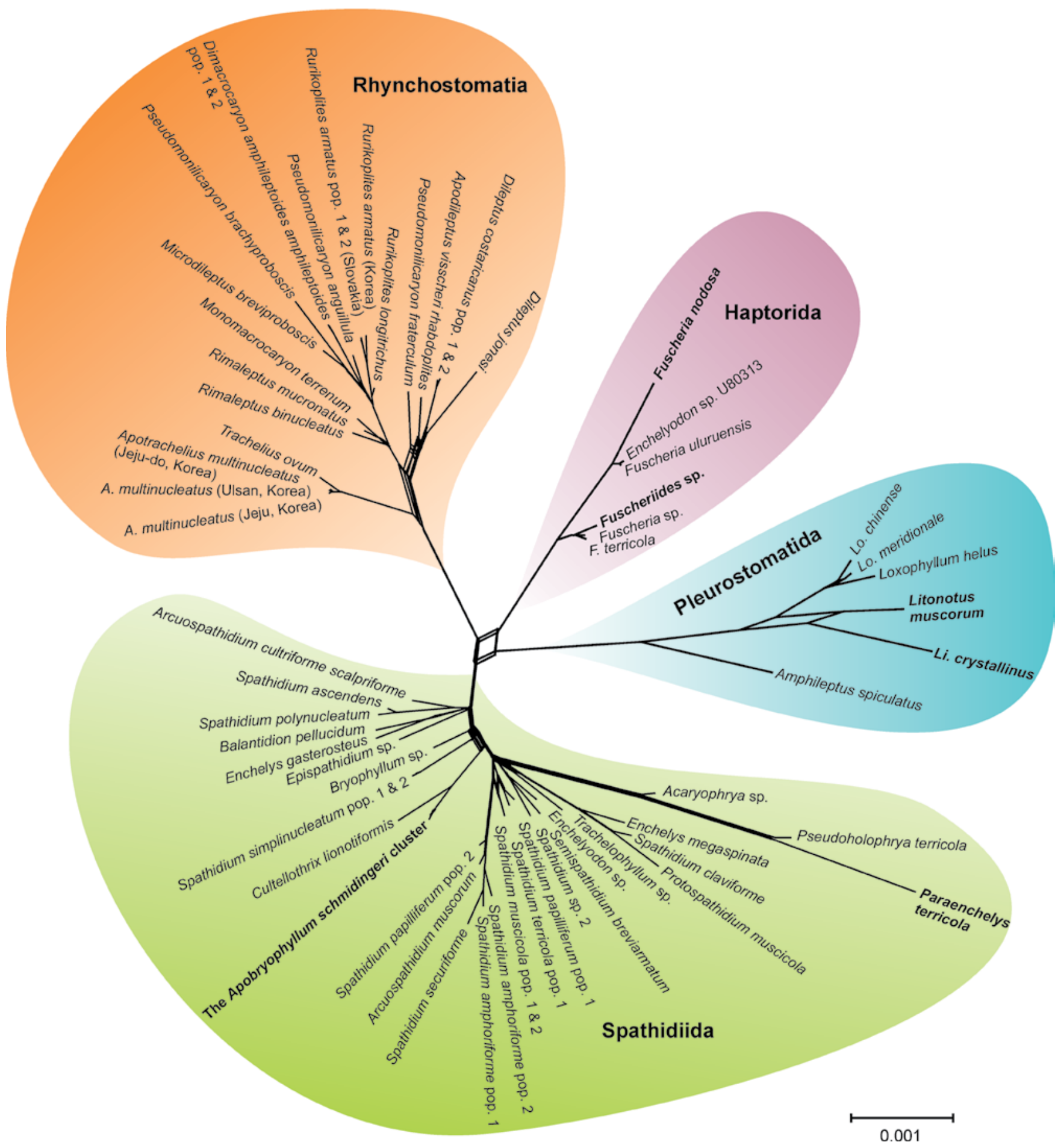

Fig. 4. Super-network of 66 free-living litostomatean taxa constructed from 80 randomly selected post-burn-in trees from the Bayesian inference of the 18S-A-D, ITSR-C and ITSR-D as well as the CON-1 and CON-2 alignments. The super-network was constructed in the program SplitsTree, using the Z-closure option, tree size weighted mean, ten runs, and the refined heuristic technique. For details on taxa and characteristics of the alignments analyzed, see Supplementary Table S1 and S2. 


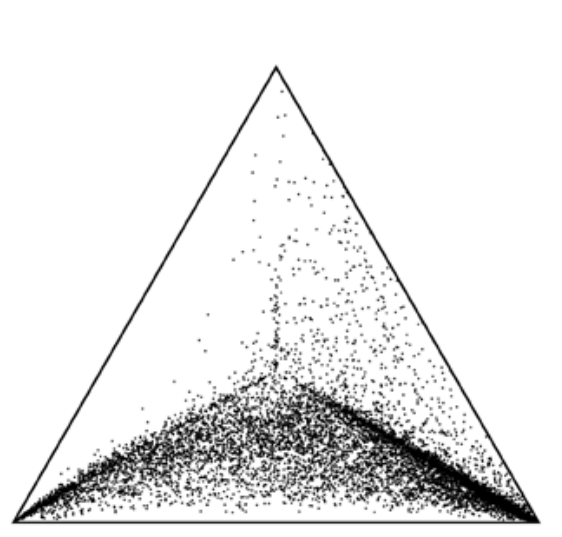

$(\mathrm{S}, \mathrm{P})-(\mathrm{R}, \mathrm{H})$

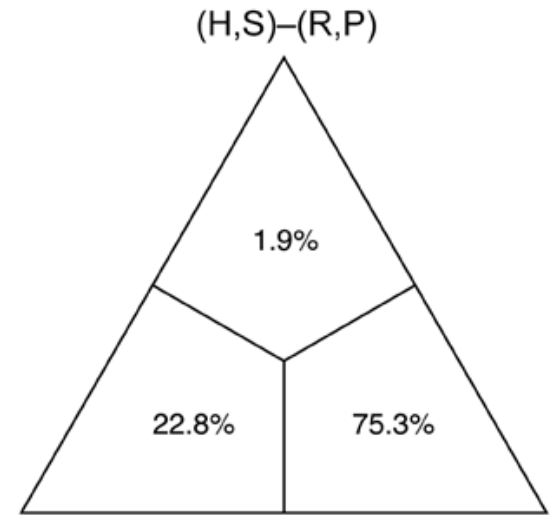

$(H, P)-(R, S)$

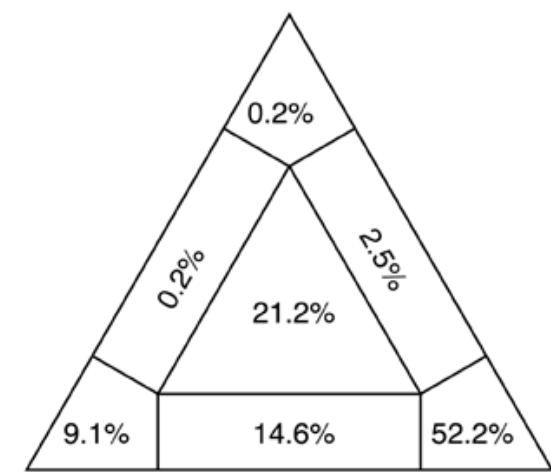

\section{S rRNA gene + ITS region}

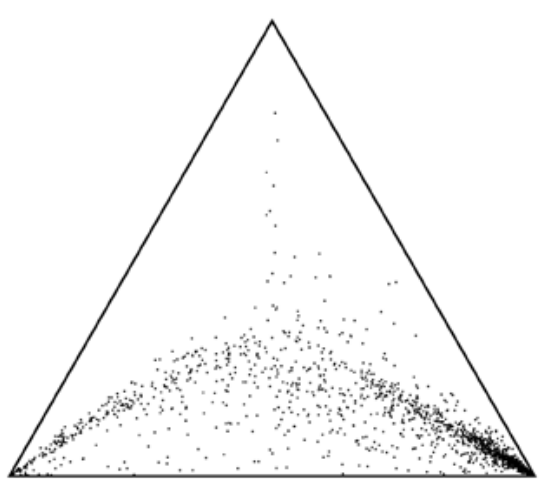

$(\mathrm{S}, \mathrm{P})-(\mathrm{R}, \mathrm{H})$
$(\mathrm{H}, \mathrm{S})-(\mathrm{R}, \mathrm{P})$

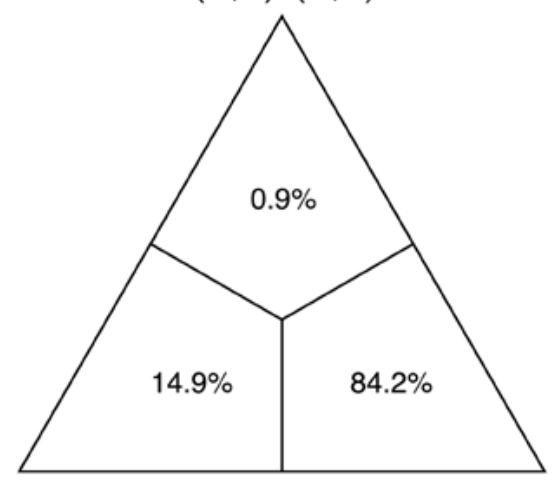

$(\mathrm{H}, \mathrm{P})-(\mathrm{R}, \mathrm{S})$

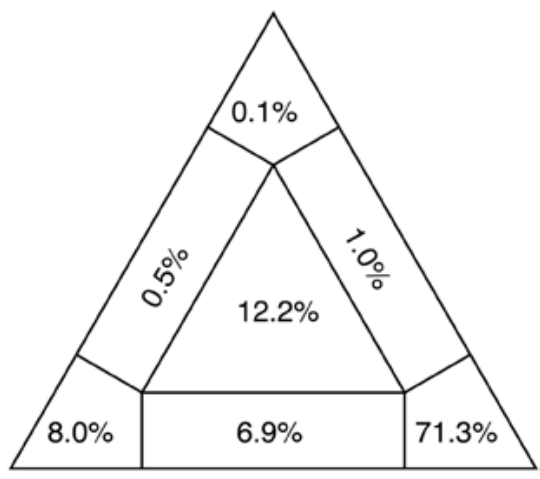

Fig. 5. Quartet likelihood-mapping showing distribution of phylogenetic signal in the 18S-A and the CON-1 alignment for three possible relationships among the four main free-living litostomatean lineages studied. The corners of the triangles show the percentage of fully resolved trees, i.e., phylogenetically informative signal. The rectangular areas show the percentage of trees that are in conflict. The central triangle shows the percentage of unresolved star-like trees, i.e., phylogenetically uninformative signal. Coding of free-living litostomatean lineages: H - Haptorida, P - Pleurostomatida, R - Rhynchostomatia, S - Spathidiida.

\section{Putative secondary structure of the ITS2 molecule}

The consensus structure of the ITS2 molecule was predicted on the Alifold webserver from 63 free-living litostomatean taxa (Table 1). As shown in Fig. 6, the consensus structure consisted of a central loop bearing two conservative helices corresponding to helix II and III of other eukaryotes (Schultz et al. 2005). In contrast, the presence and structure of helix I were much more variable among the taxa analyzed, causing difficulties in determination of its positional homology and proposal of its consensus structure.
To summarize, the consensus structure of the litostomatean ITS2 molecule revealed that: (i) helix II is composed of eight base pairs in the stem and a terminal tetraloop; (ii) helix III includes 14 base pairs, an AG bulge on the stem and a terminal heptaloop; and (iii) conservative nucleotide sites are positioned mainly in stems of both helices, while terminal loops show much more variability (Figs 6 and 7).

Furthermore, we separately predicted consensus structures of helices II and III for both free-living litostomatean subclasses (Fig. 7). The rhynchostomatian con- 


\section{L. Rajter and P. Vd'ačný}

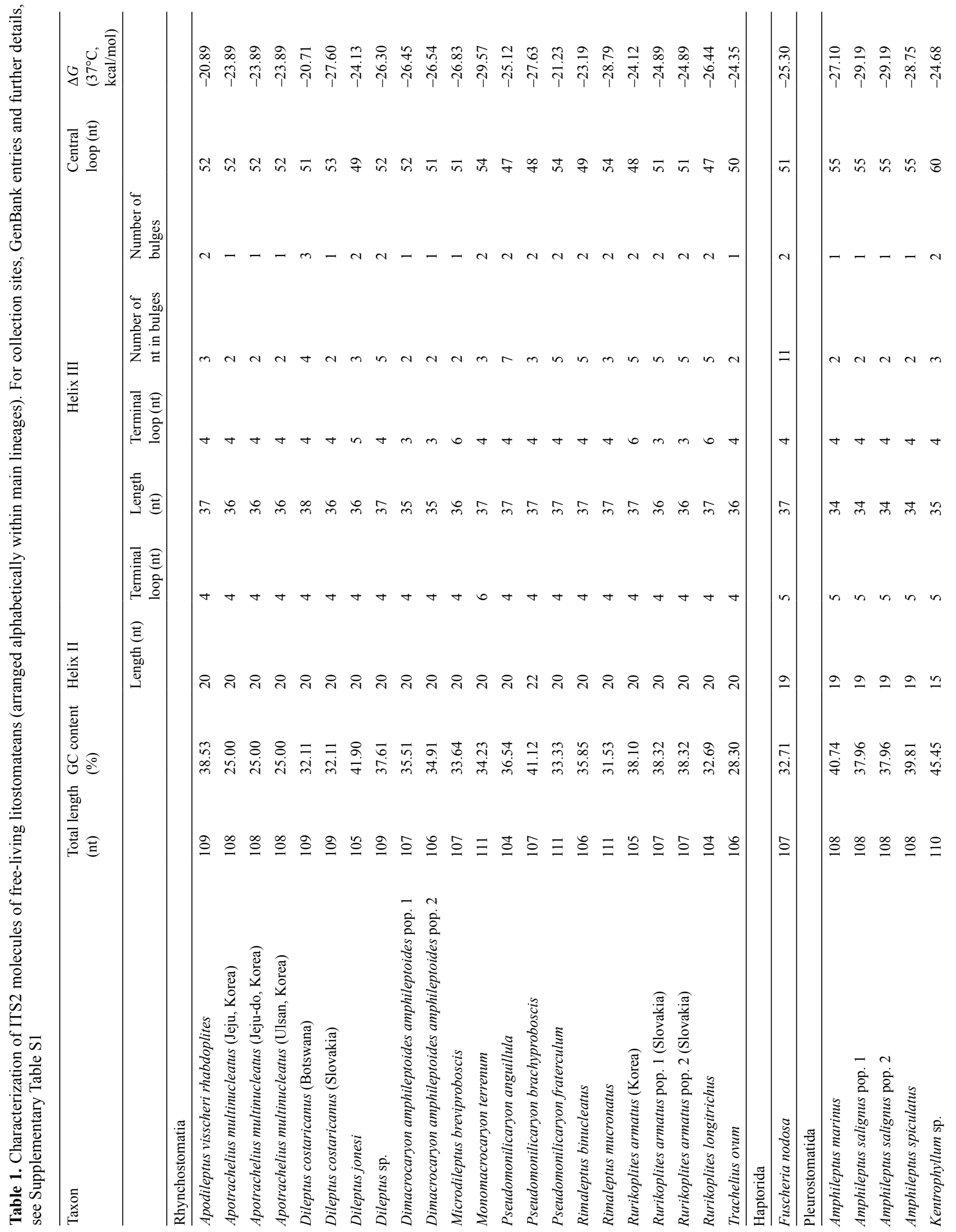




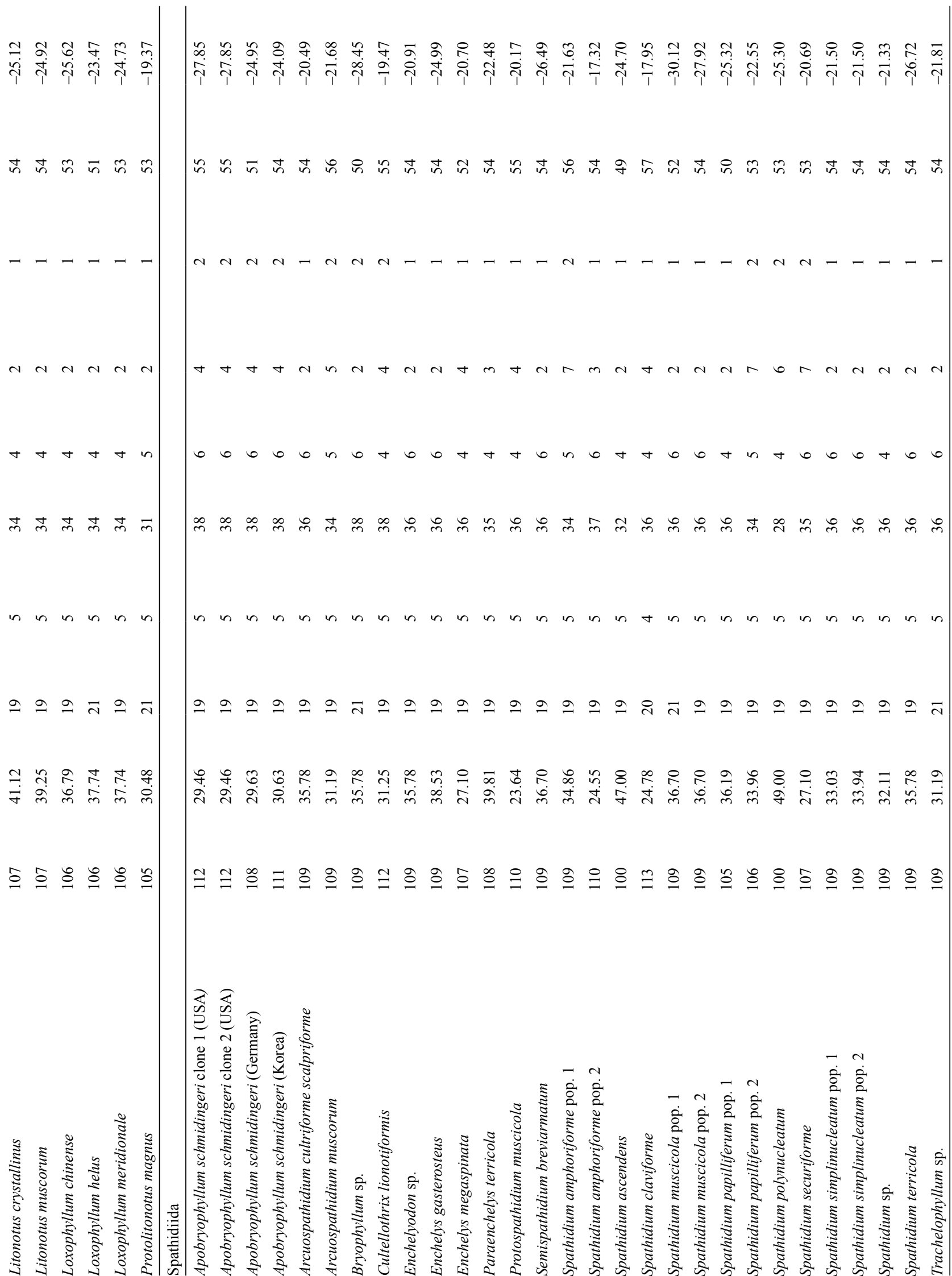




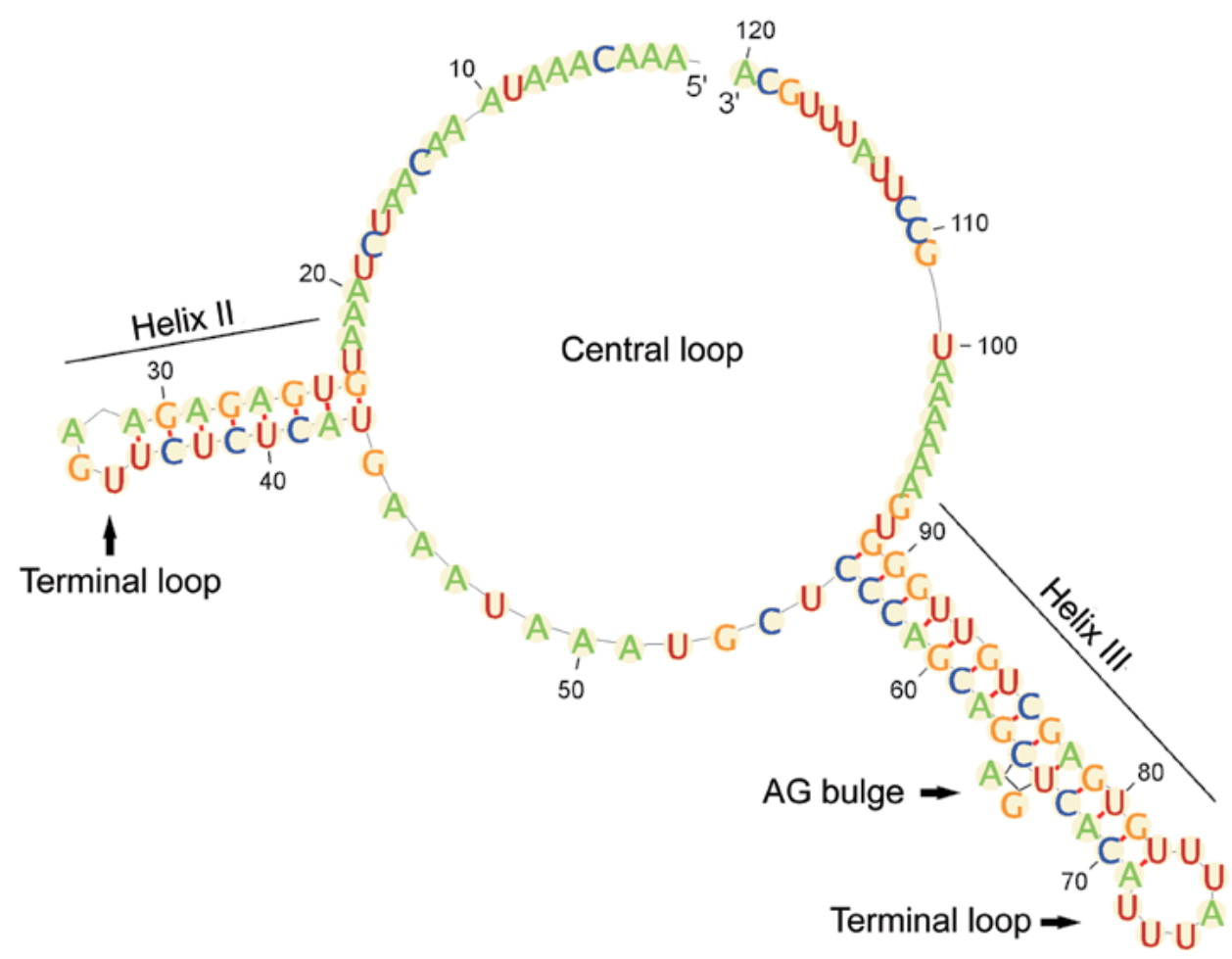

Fig. 6. Consensus secondary structure of the ITS 2 molecule of free-living litostomateans. The ITS2 molecule shows an internal loop, radiating two helices. There is an A-G bulge in the stem of helix III.

sensus structure of helix II contained eight base pairs in the stem and a terminal tetraloop in contrast to the haptorian helix II which included seven base pairs in the stem and a terminal pentaloop. The consensus structure of the rhynchostomatian helix III displayed 15 base pairs in the stem and a terminal tetraloop, whereas 14 base pairs and a terminal hexaloop were found in the haptorian helix III. Thus, the consensus stems of helices II and III were longer by one base pair in the subclass Rhynchostomatia, while the terminal loops of helices II and III were longer by one or two nucleotide/-s in the subclass Haptoria. Interestingly, the more conservative helix II showed a similar structural pattern between consensuses of the class Litostomatea and the subclass Rhynchostomatia (eight base pairs in the stem and a terminal tetraloop). This indicates a plesiomorphic nature of the rhynchostomatian helix II on one hand and an apomorphic character of the haptorian helix II on the other one.

As concerns the subclass Haptoria, consensus secondary structures of helices II and III were separately predicted for the orders Haptorida, Pleurostomatida and Spathidiida. However, in case of haptorids, only a sin- gle ITS2 sequence was available from Fuscheria nodosa. The length of stems and terminal loops in helix II were the same among all consensus structures, while numbers of nucleotides in stems and loops of helix III were different. For instance, the consensus structure of helix III in the orders Pleurostomatida and Haptorida exhibited a terminal tetraloop, whereas there was a hexaloop in the order Spathidiida. On the other hand, the number of base pairs in the consensus helix III stem was the same in the orders Spathidiida and Pleurostomatida, i.e., there were 14 pairing nucleotides. However, there were 11 pairing nucleotides and nine mismatch nucleotides, forming an asymmetrical internal loop, in the order Haptorida represented by F. nodosa.

\section{Conserved and variable nucleotide positions of heli- ces of the ITS2 molecule}

According to RNA logo analyses, the litostomatean helix II displays a conserved motif 5'-GU-GAGA-3' with an antiparallel RNA sequence 5'-UCUC-AU-3' at its stem (Figs 6-8). Dashes in the motif represent variable nucleotide sites at the class level, but there might be 
Litostomatea Helix II:

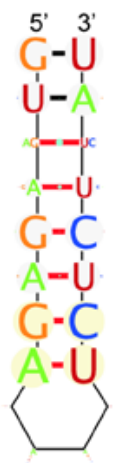

Rhynchostomatia

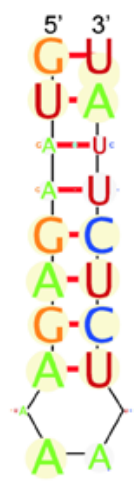

Haptoria

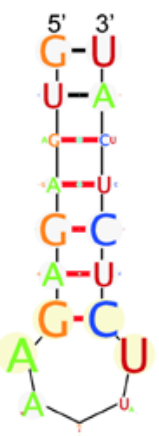

Haptorida

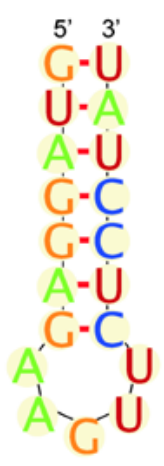

Helix III:

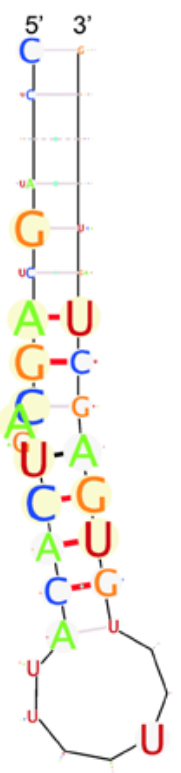

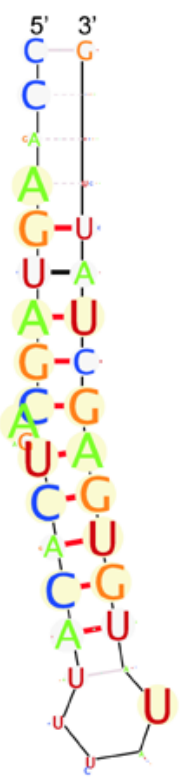
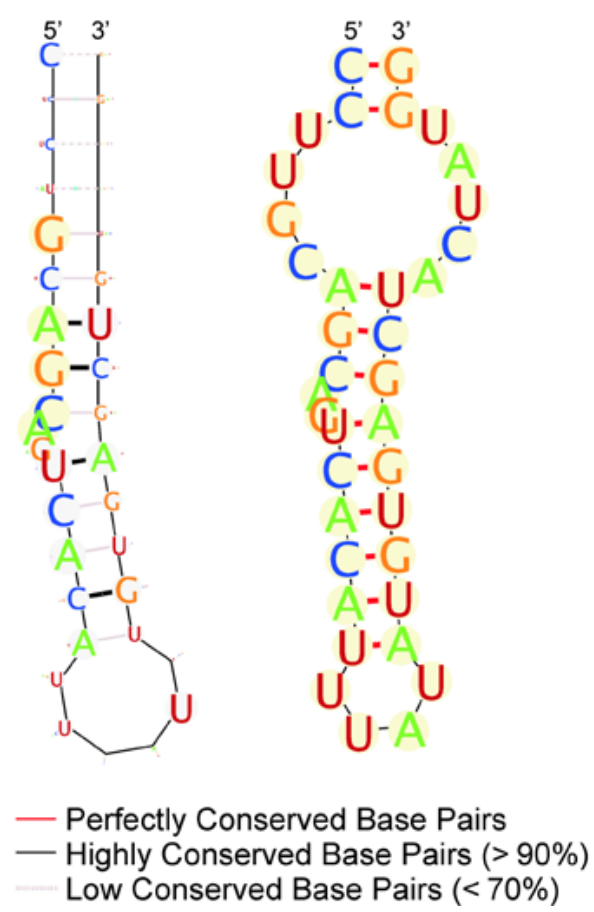

Pleurostomatida

Spathidiida
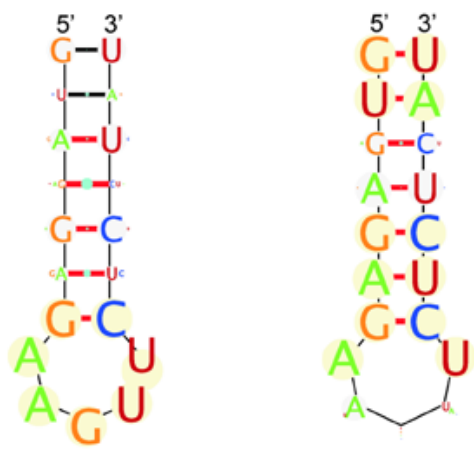

Fig. 7. Consensus secondary structure of ITS2 helices II and III in various higher litostomatean taxa.

present a certain pattern at lower taxonomic levels. For instance, within the subclass Rhynchostomatia, the variable sites are always 5'-AA-3' with the opposite strand carrying 5'-UU-3' in tracheliids, while 5'-AA-3' and 5'-GG-3' with the opposite strand bearing 5'-UU-3' and 5'-CC-3', respectively, in dileptids. The invariable pattern of tracheliids may indicate their plesiomorphic nature within the Rhynchostomatia, while the nucleotide diversity of dileptids might reflect their derived nature. In the subclass Haptoria, the variable sites of the helix
II stem are 5'-GA-3' and 5'-AG-3' with antiparallel sequences being 5'-UC-3' and 5'-CU-3', respectively. The orders Haptorida and Pleurostomatida show a 5'-AG-3' vs. 5'-CU-3' variant, while the order Spathidiida exhibits, on the contrary, a 5'-GA-3' vs. 5'-UC-3' variant. This molecular signature may further support the closeness of haptorids and pleurostomatids. Interestingly, helix II of pleurostomatids displays a rather variable nucleotide composition in the stem, while nucleotides of the terminal loop are absolutely conserved. On the 


\section{Litostomatea}

Helix II:

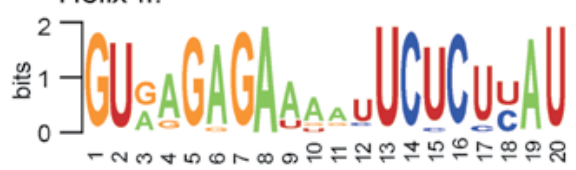

Rhynchostomatia

Helix II:

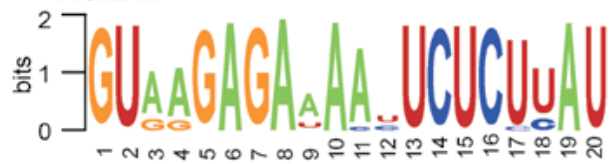

Haptoria

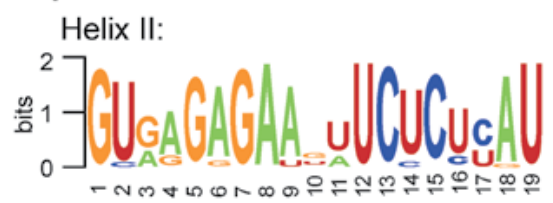

\section{Haptorida}

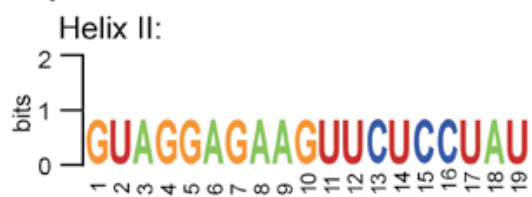

Pleurostomatida

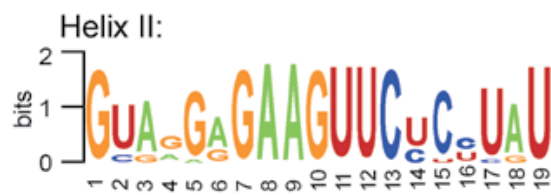

Spathidiida

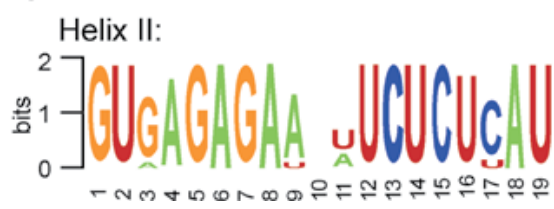

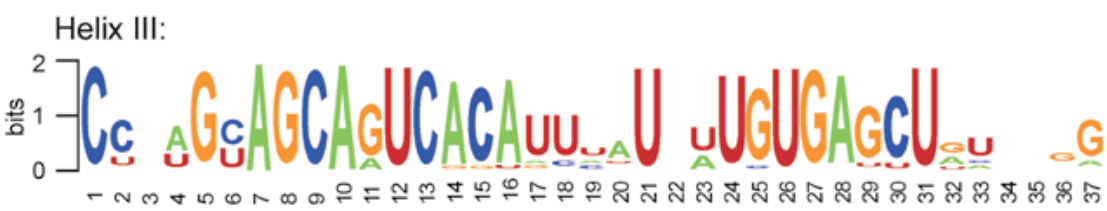
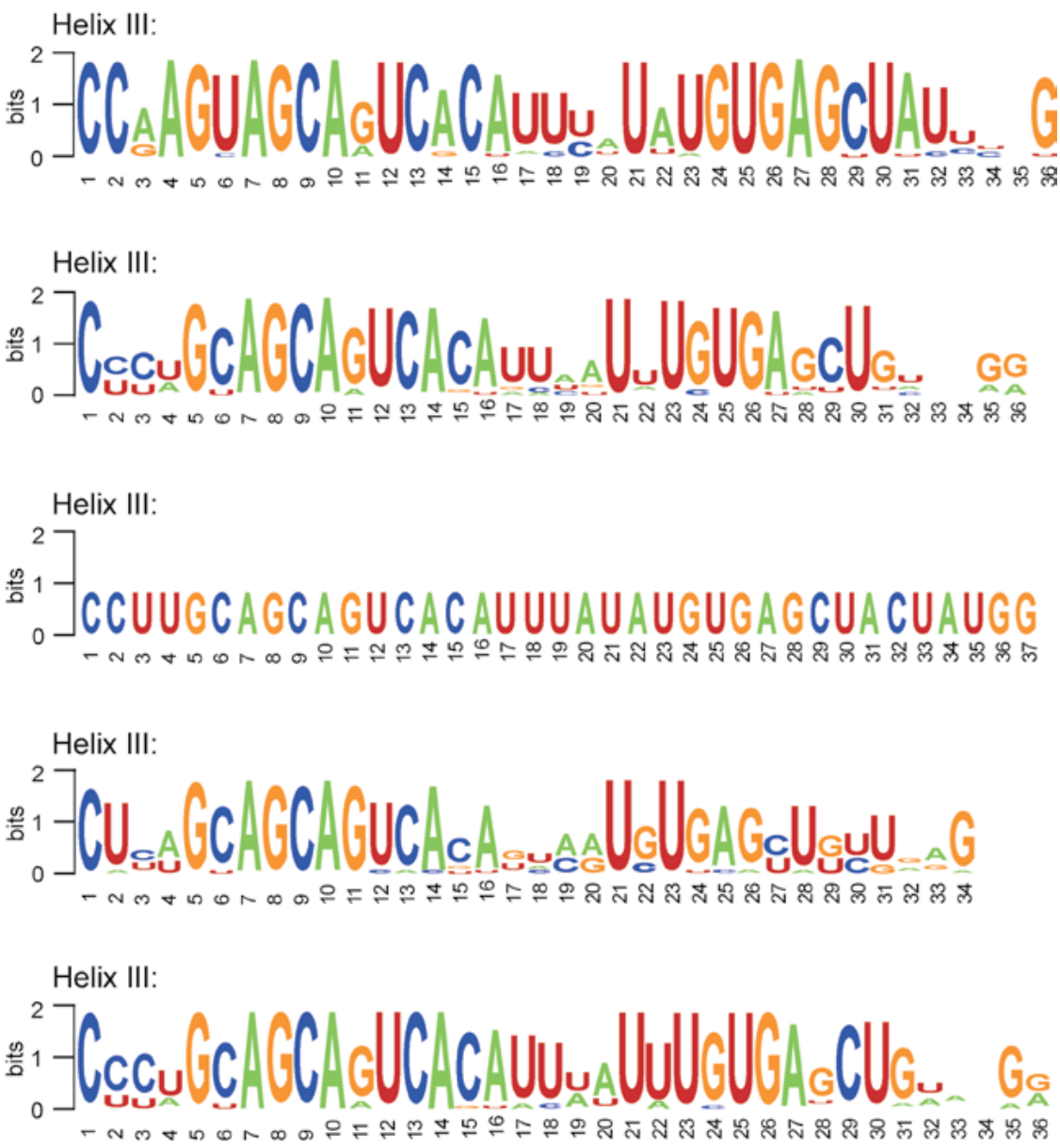

Fig. 8. Structure logo of ITS2 helices II and III in various higher litostomatean taxa. The height of a base is proportional to its frequency in multiple sequence alignments.

other hand, although spathidiids are a highly diverse group, the nucleotide composition of their helix II stem is most strongly conserved among all higher free-living litostomatean taxa, supporting the monophyletic origin of spathidiids (Fig. 7).

The basal part of the litostomatean helix III stem is more variable than the second part that shows a highly conservative motif 5'-AGCA-UCACA vs. UGUGAGCU-3' (Figs 6-8). Interestingly, the subclass Rhynchostomatia has a more conservative RNA logo for helix III than the subclass Haptoria does (Fig. 8). No particular pattern was detected either in the variable or the conservative part of helix III for the three haptorian orders studied.

\section{DISCUSSION}

\section{Phylogenetic interrelationships between free-living litostomateans}

According to Vd'ačný et al. (2011a), free-living ciliates of the class Litostomatea are classified into two 
subclasses altogether having seven main lineages/orders. Specifically, the first subclass Rhynchostomatia includes the orders Tracheliida and Dileptida, while the subclass Haptoria contains the orders Haptorida, Pleurostomatida, Didiniida, Lacrymariida, and Spathidiida. Monophylies of all these orders, except for spathidiids, are well supported by morphological apomorphies and 18S rRNA gene sequences (e.g. Vd'ačný et al. 2011a, 2014). However, the evolutionary interrelationships among the haptorian orders are very poorly resolved and understood (e.g. Zhang et al. 2012; Vd'ačný et al. 2014; Gao et al. 2016; Vd'ačný and Rataj 2017).

A comparatively broad sampling of four molecular markers (18S and 5.8S rRNA genes as well as internal transcribed spacers 1 and 2) is now available for four free-living litostomatean groups, i.e., rhynchostomatians, haptorids, pleurostomatids, and spathidiids. All present phylogenetic analyses and the mid-point rooting method consistently indicate that there is a deep split between rhynchostomatians and the three haptorian orders studied. This result corresponds well with some recent molecular studies based on the 18S rRNA gene (e.g. Strüder-Kypke et al. 2006; Gao et al. 2008; Vd'ačný et al. 2010, 2011a, 2011b, 2014; Rajter and Vd'ačný 2016) and is also corroborated by the specific length of stems and loops of helices II and III of the ITS2 molecule. Specifically, there are eight and $15 \mathrm{nu}$ cleotide pairs in helix II and III in rhynchostomatians, while seven and 14 nucleotide pairs in helix II and III in haptorians. Moreover, rhynchostomatians exhibit a terminal tetraloop both in helix II and III, while haptorians very likely had ancestrally a pentaloop in helix II and a hexaloop in helix III (Fig. 9).

Rhynchostomatians also differ conspicuously from haptorians morphologically in having a proboscis and a complex oral ciliature composed of a circumoral and a perioral kinety as well as of multiple preoral kineties (Vd’ačný and Foissner 2012). In spite of this, rhynchostomatians were traditionally assigned to various haptorian groups in morphology-based frameworks (e.g. Kahl 1931; Corliss 1974; Foissner and Foissner 1988; Lipsomb and Riordan 1990; Lynn 2008). However, already the first molecular studies about litostomatean phylogeny have uncovered rhynchostomatians and remaining free-living litostomateans (i.e. haptorians) to be independent lineages (Strüder-Kypke et al. 2006; Gao et al. 2008; Vd'ačný et al. 2010, 2011a, 2011b). Indeed, members of the subclass Rhynchostomatia exhibit some important ciliate plesiomorphic features: the aforementioned complex oral ciliature where circumoral kinety corresponds to paroral membrane and preoral kineties to adoral membranelles of other ciliates, the ventral cytostome located at the base of the proboscis, and anarchic fields produced during stomatogenesis (Vd'ačný and Foissner 2009; Vd'ačný et al. 2010, 2011a, 2011b, 2012). In contrast, haptorians display several derived morphological and morphogenetical features: a simple oral ciliature, an apical cytostome, and a non-complex stomatogenesis without formation of anarchic fields (Foissner 1996). This suite of characters led to a hypothesis that haptorians became secondarily simplified due to body polarization (Vd'ačný et al. 2011a, 2012). The derived nature of haptorians is indicated also by the present secondary structure analyses of the ITS2 molecule. Thus, the more conservative helix II shows a similar structural pattern between consensuses of the class Litostomatea and the subclass Rhynchostomatia, which in turn indicates the apomorphic character of the haptorian helix II (see above).

As concerns the subclass Haptoria, evolutionary relationships among its orders are considered unclear in both morphological and molecular phylogenies (e.g. Strüder-Kypke et al. 2006; Gao et al. 2008; Zhang et al. 2012; Vd'ačný et al. 2014; Kwon et al. 2014; Rajter and Vd'ačný 2016; Vd'ačný and Rataj 2017). However, the present study cast more light onto this problem. Spathidiids are shown as a distinct and independent lineage, while pleurostomatids and haptorids are depicted as sister groups (Figs 1-4). This evolutionary scenario is also favored by quartet likelihood-mapping (Fig. 5) and is supported by the secondary structure of the ITS2 molecule (Figs 7 and 8). Specifically, haptorids and pleurostomatids share a terminal tetraloop in helix III as well as a 5'-AG vs. CU-3' motif in the variable part of helix II. On the contrary, members of the order Spathidiida maintained the plesiomorphic terminal hexaloop in helix II and evolved a unique 5'-GA vs. UC-3' variant in the variable part of helix II (Fig. 9). Interestingly, pleurostomatids and haptorids also display meridionally extending somatic kineties and a non-three-rowed dorsal brush (Fig. 9). On the contrary, spathidiids typically exhibit anteriorly curved somatic kineties and a threerowed dorsal brush with anterior monokinetidal tails. In accordance with structural conservatism hypothesis, we suppose that somatic kineties are evolutionary conservative structures, reflecting closeness of pleurostomatids and haptorids. Indeed, dorsal brush seems to carry evolutionary information about segregation of the main free-living litostomatean lineages (Kwon et al. 2014). In this light, didiniids, lacrymariids and chaeneids 


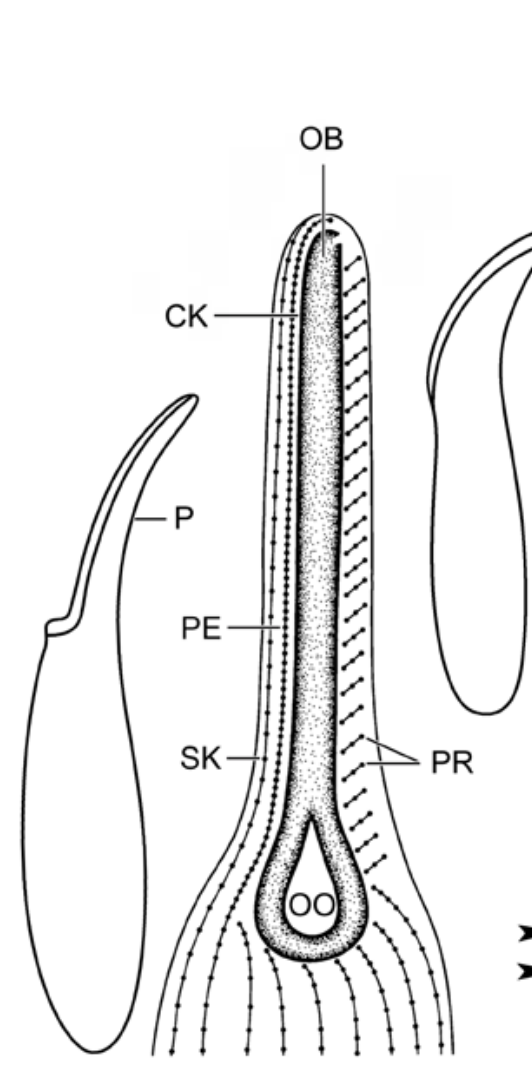

Rhynchostomatia

Helix II

Helix III
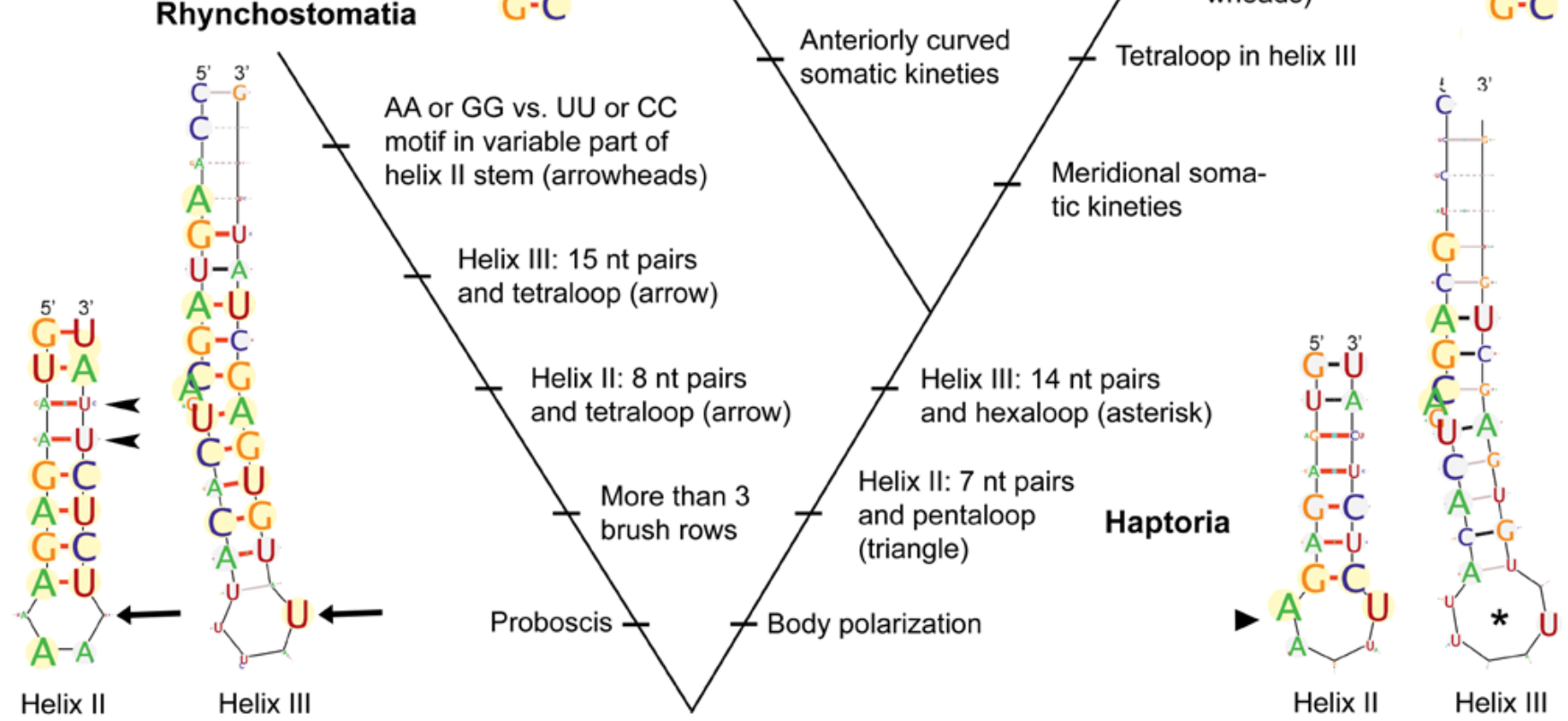

AA or GG vs. UU or CC motif in variable part of helix II stem (arrowheads)

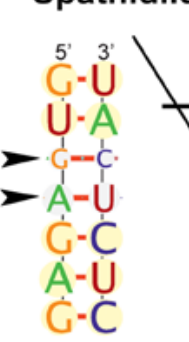

GA vs. UC motif in variable part of helix II stem (arrowheads)

Pleurostomatida

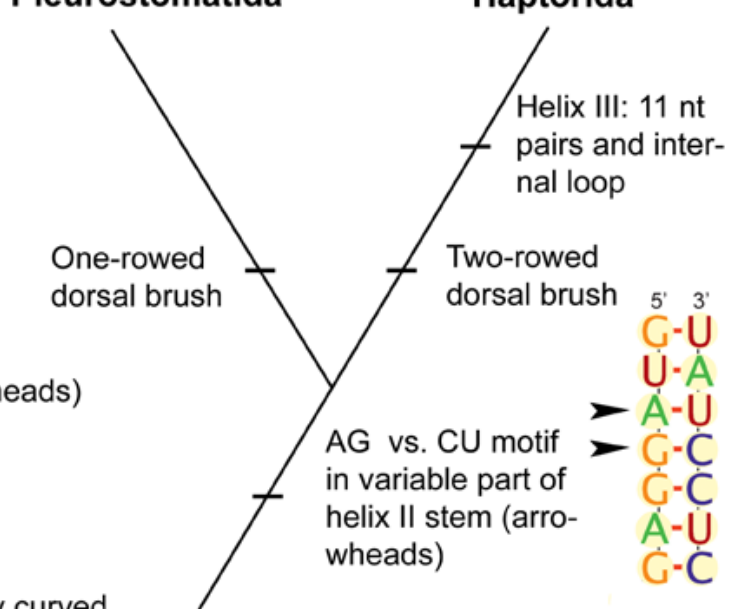
wheads)

Fig. 9. Evolutionary hypothesis of interrelationships among the four free-living litostomatean lineages studied. This scenario was suggested on the basis of morphology and the consensus secondary structure of the ITS2 molecules. CK - circumoral kinety, DB - dorsal brush, OB oral bulge, $\mathrm{OO}$ - oral bulge opening, $\mathrm{P}$ - proboscis, $\mathrm{PE}$ - perioral kinety, $\mathrm{PR}$ - preoral kineties, $\mathrm{SK}$ - somatic kineties. 
appear to be more closely related to spathidiids than to pleurostomatids and haptorids. Interestingly, didiniids, lacrymariids and chaeneids exhibit anteriorly curved or even spiraling somatic kineties and their dorsal brush begins with anterior monokinetidal tails as well. A relatedness of spathidiids, didiniids, lacrymariids and chaeneids is also indicated by genes coding for the $28 \mathrm{~S}$ rRNA molecule and alpha-tubulin (Zhang et al. 2012).

\section{Monophyly of the order Spathidiida}

The highly diverse order Spathidiida was established by Foissner and Foissner (1988) on the basis of oral infraciliature as well as localization and shape of the cytostome. Later on, spathidiids were redefined in the light of molecular analyses that indicated didiniids to be excluded from the order Spathidiida and several 'traditional' haptorids (e.g., Acropisthiidae Foissner and Foissner, 1988 and Enchelyidae Ehrenberg, 1838 ) to be included among spathidiids (Vd’ačný et al. 2011a). The ancestrally tree-rowed dorsal brush with anterior monokinetidal tails and the anteriorly curved somatic kineties became the best diagnostic features of the order Spathidiida (Vd'ačný and Foissner 2013; Rajter and Vd'ačný 2016). However, the apomorphic/ plesiomorphic nature of these diagnostic characters remains questionable and is discussed below.

A three-rowed dorsal brush was very likely a property of the last common ancestor (LCA) of the subclass Haptoria (Kwon et al. 2014), suggesting its plesiomorphic condition in spathidiids. However, at the present state of knowledge, we cannot exclude that the threerowed brush was not a property of the LCA of the Haptoria and evolved convergently in Trachelius ovum from the subclass Rhynchostomatia and the LCA of spathidiids. The anteriorly curved somatic kineties were very likely present both in the LCA of the spathidiids and the LCA of the subclass Haptoria (Vd'ačný and Foissner 2013). Thus, spathidiids could directly inherit this pattern from the LCA of the subclass Haptoria, suggesting its plesiomorphic character, or might have evolved it independently, indicating its apomorphic but homoplastic nature. Interestingly, some 'traditional' haptorids (e.g. Enchelyodon and Lagynophrya), with meridionally extending ciliary rows, were also assigned to the spathidiid cluster (Vd'ačný and Foissner 2013). This ciliary pattern, however, apparently evolved convergently between haptorids and these 'traditional' haptorids (Vd'ačný et al. 2011a). Nonetheless, the combination of the ancestrally three-rowed dorsal brush and the anteriorly curved somatic kineties seems to be, at the present state of knowledge, the best diagnostic characteristics separating spathidiids from other orders of the subclass Haptoria.

Statistical support for the monophyletic origin of spathidiids is, however, low in molecular analyses. The spathidiid clade was usually recognized only in $18 \mathrm{~S}$ rRNA gene trees but with very poor statistical support. In the present ITS region trees, it was left unsupported, but in the Bayesian trees based on the concatenated $18 \mathrm{~S}$ rRNA gene and ITS region dataset, statistical support for spathidiid monophyly achieved a value of 0.94 , which is only slightly below the level of significance. Therefore, we assume that addition of further molecular markers would increase statistical support for monophyletic origin of the order Spathidiida.

\section{Phylogenetic home of the family Pseudoholophryi- dae}

The family Pseudoholophryidae was founded by Berger et al. (1984) on the basis of the absence of dorsal brush. Later on, Foissner and Foissner (1988) improved diagnostic features of pseudoholophryids after reinvestigation of several Pseudoholophrya terricola populations. They recognized that this species carries a diffuse dorsal brush composed of many clavate bristles alternating with typical somatic cilia. Besides the genus Pseudoholophrya Foissner, 1984, the genera Ovalorhabdos Foissner, 1984 and Paraenchelys Foissner, 1983 also exhibit the same unique brush pattern and were therefore included into the family Pseudoholophryidae. Foissner et al. (2002) elevated pseudoholophryids from the family to the order rank, because of the diffuse dorsal brush, the spiraling somatic kineties, and the small size of the cytostome. Recently, based on the 18S rRNA gene, we discovered that pseudoholophryids might represent a spathidiid lineage that is closely related to the genus Acaryophrya André, 1915 (Rajter and Vd'ačný 2016). Therefore, we suppressed the order Pseudoholophryida, transferred the family Pseudoholophryidae into the order Spathidiida, and assigned the genus Acaryophrya to the family Pseudoholophryidae. For the first time, we have the possibility to more robustly test the monophyly of this family by molecular methods. According to the present phylogenetic trees, the 18S rRNA gene sequence of Paraenchelys terricola clusters together with/near to Pseudoholophrya terricola and Acaryophrya sp. But monophyletic origin of Pseudoholophrya, Paraenchelys, and Acaryophrya is either poorly statistically supported or is left unsupported. However, since these three genera form 
a distinct clade in multiple post burn-in Bayesian trees, the family Pseudoholophryidae became the best recognizable lineage within the spathidiid cluster in the present super-network analyses (Fig. 4). Therefore, we believe that addition of further molecular markers might lead to strong statistical support for pseudoholophryids, as redefined by Rajter and Vd'ačný (2016).

\section{Putative secondary structure of the free-living litos- tomatean ITS2 molecule}

The ITS2 region is located between the 5.8S rRNA and the 28S rRNA gene in the rRNA locus. The ITS2 molecule participates in maturation processes of both aforementioned rRNA molecules. The presence of deletions or mutations within ITS2 leads to failure in production of mature rRNA molecules, as evidenced by many experimental studies (e.g. van Nues et al. 1994; Côté et al. 2002; Ferreira-Cerca 2008 and references therein). Thus, ITS2 plays an important role in transcript processing and hence remains rather conservative in its primary and secondary structure among many eukaryotes (Coleman 2003; Schultz et al. 2005; Wolf et al. 2005). Therefore, this molecule has become a popular tool in many phylogenetic studies, including those on ciliates (e.g. Coleman 2005; Miao et al. 2008; Weisse et al. 2008; Yi et al. 2008; Sun et al. 2010, 2013; Ponce-Gordo et al. 2011; Vd'ačný et al. 2012; Li et al. 2013; Shazib et al. 2016; Li et al. 2017).

The ITS2 region has a comparatively similar length in all free-living litostomatean taxa, ranging from 100 to 112 nucleotides (Ponce-Gordo et al. 2011; Vd’ačný et al. 2012; Jang et al. 2014; present study). Interestingly, this is the shortest ITS2 region among all already investigated ciliates from the subphylum Intramacronucleata. Specifically, the length of ITS2 sequences varies from 168 to $169 \mathrm{nt}$ within the genus Paramecium (Coleman 2005), from 168 to $217 \mathrm{nt}$ in scuticociliates (Miao et al. 2008), and from 165 to $175 \mathrm{nt}$ in peritrichs (Sun et al. 2010, 2013). Spirotrichean ciliates exhibit the longest ITS2 sequences typically exceeding 200 nucleotides (Weisse et al. 2008; Yi et al. 2008; Li et al. 2013, 2017). On the other hand, the genera Spirostomum and Anigsteinia from the class Heterotrichea of the subphylum Postciliodesmatophora display the shortest ITS2 sequences, being only 79-81 nt long, among all ciliates hitherto studied (Shazib et al. 2016).

Two alternative secondary structures of the ITS2 molecule were proposed for ciliates: a ring and a hairpin model. In the ring model, a common loop bears two helices in heterotricheans (Shazib et al. 2016), two to three helices in litostomateans (Ponce-Gordo et al. 2011; present study) and spirotricheans (Weisse et al. 2008; Yi et al. 2008, Li et al. 2013, 2017), and three to four helices in scuticociliates (Miao et al. 2008). In the hairpin model, the common loop is started and closed by helix I and radiates helices II and III in peritrichs (Sun et al. 2010) and litostomateans (Vd'ačný et al. 2012). Interestingly, both ITS2 models were detected in litostomateans, the ring model by Ponce-Gordo et al. (2011) and the hairpin model by Vd'ačný et al. (2012). The existence of two models could be explained by the dynamic conformational model proposed by Côté et al. (2002). The ring structure forms during early events of rRNA maturation, while the hairpin structure during the subsequent processing events. Regardless of the model used, the structure and motifs of helices II and III are conservative among various ciliate groups. Thus, there is a pyrimidine-pyrimidine mismatch in helix II of heterotricheans (Shazib et al. 2016) and oligohymenophoreans (Coleman 2005; Miao et al. 2008; Sun et al. 2010, 2013), as typical for eukaryotes (Coleman 2007; Schultz et al. 2005). By contrast, this mismatch is not present in litostomateans and spirotricheans (Weisse et al. 2008; Yi et al. 2008; Li et al. 2013, 2017). This indicates that the loss of the pyrimidine-pyrimidine mismatch is a molecular synapomorphy of litostomateans and spirotricheans, providing a further support for the SAL hypothesis based on extensive molecular data (Gentekaki et al. 2014, 2017). Since both models match very well in the structure and motifs of helices II and III but differ in helix I, this structure is very likely the dynamic constituent of the ITS2 transcripts, enabling switching from the ring to the hairpin pattern (Vd'ačný et al. 2012).

\section{Comparison of ITS2 molecules of free-living and en- dosymbiotic litostomateans}

The secondary structure of the ITS2 molecule was studied only in three species of endosymbiotic litostomateans from the subclass Trichostomatia, i.e., in Balantidium coli, Isotricha prostoma and Troglodytella abrassarti (Ponce-Gordo et al. 2011). The trichostomatian ITS2 primary and secondary structures match very well those of free-living litostomateans. Specifically, the trichostomatian ITS2 molecule (i) exhibits three helices, with helix I being the shortest and helix III being the longest; (ii) lacks the pyrimidin-pyrimidin mismatch in helix II; and (iii) displays the conservative motif 5'-GU-GAGA vs. UCUC-AU-3' in helix II. As in free-living haptorians, there are seven pairs and 
a pentaloop in the trichostomatian helix II. However, trichostomatians display a motif 5'-AA vs. UU-3' or 5'-AU vs. AU-3' in the variable part of helix II. The first motif occurs also in tracheliids and dipletids, which indicates its homoplastic nature, while the second motif is unique to trichostomatians.

\section{CONCLUSIONS}

Utilization of the 18S rRNA gene along with the ITS region is revealed to be beneficial for phylogenetic inferences in ciliates, because concatenation of the comparatively conservative $18 \mathrm{~S}$ rRNA gene sequences with the faster evolving ITS region sequences might lead to increasing statistical support in phylogenetic trees. Moreover, the conservative parts of helix II and III of the ITS2 molecule might serve as a good proxy for reconstruction of not only recent but also deep evolutionary events. And finally molecular phylogenetic analyses of the 18S rRNA gene and the ITS region harmonize well with assumptions based on the structural conservatism hypothesis, postulating that somatic ciliary structures are phylogenetically more informative than oral patterns.

Acknowledgements. We are very grateful to two anonymous reviewers for their constructive criticism and thoughtful comments. This work was supported by the Slovak Research and Development Agency under the contract No. APVV-15-0147 and by the Grant Agency of the Ministry of Education, Science, Research and Sport of the Slovak Republic and Slovak Academy of Sciences under the Grants VEGA 1/0041/17 and VEGA 1/0114/16. This study was also supported by the Comenius University in Bratislava under the Grant No. UK/400/2017.

\section{REFERENCES}

Alfaro M. E., Zoller S., Lutzoni F. (2003) Bayes or bootstrap? A simulation study comparing the performance of Bayesian Markov Chain Monte Carlo sampling and bootstrapping in assessing phylogenetic confidence. Mol. Biol. Evol. 20: 255-266

André E. (1915) Recherches sur la faine pélagique du Léman et description de neoveaux genres d'infusoires. Revue Suisse Zool. 22: 179-193

Berger H., Foissner W., Adam H. (1984). Taxonomie, Biometrie und Morphogenese einiger terricoler Ciliaten (Protozoa: Ciliophora). Zool. Jahrb. Syst. 111: 339-367

Bernhart S. H., Hofacker I. L., Will S., Gruber A. R., Stadler P. F. (2008) RNAalifold: improved consensus structure prediction for RNA alignments. BMC Bioinformatics 9: 474

Chang T.-H., Horng J.-T., Huang H.-D. (2008) RNALogo: a new approach to display structural RNA alignment. Nucleic Acids Res. 36: W91-W96
Coleman A. W. (2003) ITS2 is a double-edged tool for eukaryote evolutionary comparisons. Trends Genet. 19: 370-375

Coleman A. W. (2005) Paramecium aurelia revisited. J. Eukaryot. Microbiol. 52: 68-77

Coleman A. W. (2007) Pan-eukaryote ITS2 homologies revealed by RNA secondary structure. Nucleic Acids Res. 35: 3322-3329

Corliss J. O. (1974) The changing world of ciliate systematics: historical analysis of past efforts and a newly proposed phylogenetic scheme of classification for the protistan phylum Ciliophora. Syst. Zool. 23: 91-138

Côté C. A., Greer C. L., Peculis B. A. (2002) Dynamic conformational model for the role of ITS2 in pre-rRNA processing in yeast. $R N A$ 8: 786-797

Ehrenberg C. G. (1838) Die Infusionsthierchen als vollkommene Organismen. Ein Blick in das tiefere organische Leben der Natur. Verlag von Leopold Voss, Leipzig

Fauré-Fremiet E. (1950) Ecologie des ciliés psammophiles littoraux. Bull. Biol. Fr. Belg. 84: 35-75

Ferreira-Cerca S. (2008) Analysis of the in vivo functions and assembly pathway of small subunit ribosomal proteins in Saccharomyces cerevisiae. PhD Thesis, Universität Regensburg. Available at http://epub.uniregensburg.de/10718/1/Ferreira Cerca_S.pdf

Foissner W. (1983) Taxonomische Studien über die Ciliaten des Großglocknergebietes (Hohe Tauern, Österreich) I. Familien Holophryidae, Prorodontidae, Plagiocampidae, Colepidae, Enchelyidae und Lacrymariidae nov. fam. Ann. Nat. Hist. Mus. Wien Ser. B Bot. Zool. 84: 49-85

Foissner W. (1984) Infraciliatur, Silberliniensystem und Biometrie einiger neuer und wenig bekannter terrestrischer, limnischer und mariner Ciliaten (Protozoa: Ciliophora) aus den Klassen Kinetofragminophora, Colpodea und Polyhymenophora. Stapfia 12: $1-165$

Foissner W. (1987) Neue terrestrische und limnische Ciliaten (Protozoa, Ciliophora) aus Österreich und Deutschland. Sber. Österr. Akad. Wiss., Math.-naturwiss. Kl., Abt. I 195 (year 1986): 217-268

Foissner W. (1996) Ontogenesis in ciliated protozoa, with emphasis on stomatogenesis. In: Ciliates: Cells as Organisms, (Eds. K. Hausmann, B. C. Bradbury). Fischer Verlag, Stuttgart, Jena, New York, 95-177

Foissner W. (1997) Updating the trachelocercids (Ciliophora, Karyorelictea). IV. Transfer of Trachelocerca entzi Kahl, 1927 to the Gymnostomatea as a new genus, Trachelotractus gen. n. (Helicoprorodontidae). Acta Protozool. 36: 63-74

Foissner W. (2016) Terrestrial and semiterrestrial ciliates (Protozoa, Ciliophora) from Venezuela and Galápagos. Denisia 35: 1-912

Foissner W., Al-Rasheid K. (2007) Notes on soil ciliates (Protozoa, Ciliophora) from The Netherlands, with description of Keronopsis schminkei nov. spec. and Apobryophyllum schmidingeri nov. spec. Acta Protozool. 46: 201-220

Foissner W., Foissner I. (1988) The fine structure of Fuscheria terricola Berger et al., 1983 and a proposed new classification of the subclass Haptoria Corliss, 1974 (Ciliophora, Litostomatea). Arch. Protistenkd. 135: 213-235

Foissner W., Xu K. (2007) Monograph of the Spathidiida (Ciliophora, Haptoria). Vol. I: Protospathidiidae, Arcuospathidiidae, Apertospathulidae. Springer Verlag, Dordrecht

Foissner W., Berger H., Blatterer H., Kohmann F. (1995) Taxonomische und ökologische Revision der Ciliaten des Saprobiensystems - Band IV: Gymnostomatea, Loxodes, Suctoria. 
Informationsberichte des Bayerischen Landesamtes für Wasserwirtschaft, Deggendorf

Foissner W., Berger H., Schaumburg J. (1999) Identification and ecology of limnetic plankton ciliates. Informationsberichte des Bayerischen Landesamtes für Wasserwirtschaft, Deggendorf

Foissner W., Agatha S., Berger H. (2002) Soil ciliates (Protozoa, Ciliophora) from Namibia (Southwest Africa) with emphasis on two contrasting environments, the Etosha region and the Namib Desert. Denisia 5: 1-1459

Gabilondo R., Foissner W. (2009) Four new fuscheriid soil ciliates (Ciliophora: Haptorida) from four biogeographic regions. Acta Protozool. 48: $1-24$

Gao F., Warren A., Zhang Q., Gong J., Miao M., Sun P., Xu D., Huang J., Yi Z., Song W. (2016) The all-data-based evolutionary hypothesis of ciliated protists with a revised classification of the phylum Ciliophora (Eukaryota, Alveolata). Sci. Rep. 6: 24874

Gao S., Song W., Ma H., Clamp J. C., Yi Z., Al-Rasheid K. A. S., Chen Z., Lin X. (2008) Phylogeny of six genera of the subclass Haptoria (Ciliophora, Litostomatea) inferred from sequences of the gene coding for small subunit ribosomal RNA. J. Eukaryot. Microbiol. 55: 562-566

Gentekaki E., Kolisko M., Boscaro V., Bright K. J., Dini F., Di Giuseppe G., Gong Y., Miceli C., Modeo L., Molestina R. E., Petroni G., Pucciarelli S., Roger A. J., Strom S. L., Lynn D. H. (2014) Large-scale phylogenomic analysis reveals the phylogenetic position of the problematic taxon Protocruzia and unravels the deep phylogenetic affinities of the ciliate lineages. Mol. Phylogenet. Evol. 78: 36-42

Gentekaki E., Kolisko M., Gong Y., Lynn D. (2017) Phylogenomics solves a long-standing evolutionary puzzle in the ciliate world: the subclass Peritrichia is monophyletic. Mol. Phylogenet. Evol. 106: $1-5$

Gruber A. R., Lorenz R., Bernhart S. H., Neuböck R., Hofacker I. L. (2008) The Vienna RNA Websuite. Nucleic Acids Res. 36 (Suppl. 2): W70-W74

Guindon S., Gascuel O. (2003) A simple, fast, and accurate algorithm to estimate large phylogenies by maximum likelihood. Syst. Biol. 52: 696-704

Guindon S., Dufayard J. F., Lefort V., Anisimova M., Hordijk W., Gascuel O. (2010) New algorithms and methods to estimate maximum-likelihood phylogenies: assessing the performance of PhyML 3.0. Syst. Biol. 59: 307-321

Hall T. A. (1999) BioEdit: a user-friendly biological sequence alignment editor and analysis program for Windows 95/98/NT. Nucleic Acids Symp. Ser. 41: 95-98

Hillis D. M., Bull J. J. (1993) An empirical test of bootstrapping as a method for assessing confidence in phylogenetic analysis. Syst. Biol. 42: 182-192

Huson D. H. (1998) SplitsTree: analyzing and visualizing evolutionary data. Bioinformatics 14: 68-73

Huson D. H., Dezulian T., Kloepper T., Steel M. A. (2004) Phylogenetic super-networks from partial trees. Trans. Comp. Biol. Bioinform. 1: 151-158

Jang S. W., Vd'ačný P., Shazib S. U. A., Shin M. K. (2014) Morphological and molecular characterization of the name-bearing type species Rimaleptus binucleatus (Kahl, 1931), with a phylogenetic re-analysis of dileptid evolutionary history (Ciliophora: Litostomatea: Rhynchostomatia). Eur. J. Protistol. 50: 456-471

Jang S. W., Vd’ačný P., Shazib S. U. A., Shin M. K. (2015) Morphology, ciliary pattern and molecular phylogeny of Trachelophyl- lum brachypharynx Levander, 1894 (Litostomatea, Haptoria, Spathidiida). Acta Protozool. 54: 123-135

Jang S. W., Vd’ačný P., Shazib S. U. A., Shin M. K. (2017) Linking morphology and molecules: integrative taxonomy of spathidiids (Protista: Ciliophora: Litostomatea) from Korea. J. Nat. Hist. 51: 939-974

Jankowski A. W. [Ânkovskij A. V.] (1978) Novye vysšie taksony resničnyh prostejših (Ciliophora) [New higher taxa of ciliated protozoa (Ciliophora)]. In: Morfologiâ, sistematika i èvolûciâ životnyh. Sbornik naučnyh rabot [Morphology, systematics and evolution of animals. Set of scientific papers], (Ed. L. Â. Borkin [L. Ya. Borkin]). Akademiâ Nauk SSSR, Zool. Inst., Leningrad: 88-90 (in Russian)

Jankowski A. W. [Ânkovskij A. V.] (1980) Konspekt novoj sistemy tipa Ciliophora [Conspectus of a new system of the phylum Ciliophora]. Trudy Zool. Inst. Leningrad 94: 103-121 (in Russian)

Johnson M. D., Tengs T., Oldach D. W., Delwiche C. F., Stoecker D. K. (2004) Highly divergent SSU rRNA genes found in the marine ciliates Myrionecta rubra and Mesodinium pulex. Protist 155: 347-359

Kahl A. (1930a) Neue und ergänzende Beobachtungen holotricher Infusorien II. Arch. Protistenkd. 70: 313-416

Kahl A. (1930b) Urtiere oder Protozoa I: Wimpertiere oder Ciliata (Infusoria) 1. Allgemeiner Teil und Prostomata. Tierwelt Dtl. 18: $1-180$

Kahl A. (1931) Urtiere oder Protozoa I: Wimpertiere oder Ciliata (Infusoria) 2. Holotricha außer den im 1. Teil behandelten Prostomata. Tierwelt Dtl. 21: 181-398

Kreutz M., Foissner W. (2006) The Sphagnum ponds of Simmelried in Germany: a biodiversity hot-spot for microscopic organisms. Protozool. Monogr. 3: 1-267

Kwon C. B., Vd'ačný P., Shazib S. U. A., Shin M. K. (2014) Morphology and molecular phylogeny of a new haptorian ciliate, Chaenea mirabilis sp. n., with implications for the evolution of the dorsal brush in haptorians (Ciliophora, Litostomatea). J. Eukaryot. Microbiol. 61: 278-292

Li J., Liu W., Gao S., Warren A., Song W. (2013) Multigene-based analyses of the phylogenetic evolution of oligotrich ciliates, with consideration of the internal transcribed spacer 2 secondary structure of three systematically ambiguous genera. Eukaryot. Cell 12: 430-437

Li J., Zhan Z., Xu K. (2017) Systematics and molecular phylogeny of the ciliate genus Pseudokeronopsis (Ciliophora, Hypotrichia). J. Eukaryot. Microbiol. 64: 850-872

Lin X., Song W., Li J. (2007) Description of two new marine pleurostomatid ciliates, Loxophyllum choii nov. spec. and L. shini nov. spec. (Ciliophora, Pleurostomatida) from China. Eur. J. Protistol. 43: 131-139

Lin X., Al-Rasheid K. A. S., Al-Quaraishy S. A., Al-Farraj S. A., Song W. (2008) Identification of three highly confused marine Loxophyllum (Ciliophora: Pleurostomatida) with a key to seven congeners from the China Sea. J. Eukaryot. Microbiol. 55: 331-342

Lin X., Warren A., Song W. (2009) Pleurostomatids. In: Free-living Ciliates in the Bohai and Yellow Seas, China (Eds. W. Song, A. Warren, X. Hu). Science Press, Beijing, 93-134

Lipscomb D. L., Riordan G. P. (1990) The ultrastructure of Chaenea teres and an analysis of phylogeny of the haptorid ciliates. J. Protozool. 37: 287-330

Lynn D. H. (2008) The Ciliated Protozoa. Characterization, Classification and Guide to the literature. $3^{\text {rd }}$ ed. Springer, Dordrecht 
Medlin L., Elwood H. J., Stickel S., Sogin M. L. (1988) The characterization of enzymatically amplified eukaryotic 16S-like rRNA-coding regions. Gene 71: 491-499

Miao M., Warren A., Song W., Wang S., Shang H., Chen Z. (2008) Analysis of the internal transcribed spacer 2 (ITS2) region of scuticociliates and related taxa (Ciliophora, Oligohymenophorea) to infer their evolution and phylogeny. Protist 159: 519-533

Miller M. A., Pfeiffer W., Schwartz T. (2010) Creating the CIPRES Science Gateway for inference of large phylogenetic trees. In: Proceedings of the Gateway Computing Environments Workshop (GCE). New Orleans, LA, 1-8

Pan H., Gao F., Li J., Lin X., Al-Farraj S. A., Al-Rasheid K. A. S. (2010) Morphology and phylogeny of two new pleurostomatid ciliates, Epiphyllum shenzhenense n. sp. and Loxophyllum spirellum n. sp. (Protozoa, Ciliophora) from a mangrove wetland, South China. J. Eukaryot. Microbiol. 57: 421-428

Pan H., Gao F., Lin X., Warren A., Song W. (2013) Three new Loxophyllum species (Ciliophora: Pleurostomatida) from China with a brief review of the marine and brackish Loxophyllum species. J. Eukaryot. Microbiol. 60: 44-56

Pawlowski J. (2000) Introduction to the molecular systematics of foraminifera. Micropaleontology 46 (Suppl. 1): 1-12

Ponce-Gordo F., Fonseca-Salamanca F., Martínez-Díaz R. A. (2011) Genetic heterogeneity in internal transcribed spacer genes of Balantidium coli (Litostomatea, Ciliophora). Protist 162: 774 794

Posada D. (2008) JModelTest: phylogenetic model averaging. Mol. Biol. Evol. 25: 1253-1256

Quennerstedt A. (1867) Bidrag till sveriges infusorie-fauna. II. Acta Univ. Lund. 4: 1-48

Rajter L', Vd'ačný P. (2016) Rapid radiation, gradual extinction and parallel evolution challenge generic classification of spathidiid ciliates (Protista, Ciliophora). Zool. Scr. 45: 200-223

Schewiakoff W. [Ševâkov V.] (1896) Organizacia i sistematika infusoria Aspirotricha (Holotricha auctorum) [The organization and systematics of the infusoria Aspirotricha (Holotricha auctorum)]. Zap. Imp. Akad. Nauk (8e Série) 4: 1-395 (in Russian)

Schmidt H. A., Strimmer K., Vingron M., von Haeseler A. (2002) TREE-PUZZLE: maximum likelihood phylogenetic analysis using quartets and parallel computing. Bioinformatics 18: 502-504

Schultz J., Maisel S., Gerlach D., Müller T., Wolf M. (2005) A common core of secondary structure of the internal transcribed spacer 2 (ITS2) throughout the Eukaryota. RNA 11: 361-364

Sela I., Ashkenazy H., Katoh K., Pupko T. (2015) GUIDANCE2: accurate detection of unreliable alignment regions accounting for the uncertainty of multiple parameters. Nucleic Acids Res. 43: 7-14

Shazib S. U. A., Vd'ačný P., Kim J. H., Jang S. W., Shin M. K. (2016) Molecular phylogeny and species delimitation within the ciliate genus Spirostomum (Ciliophora, Postciliodesmatophora, Heterotrichea), using the internal transcribed spacer region. Mol. Phylogenet. Evol. 102: 128-144

Small E. B., Lynn D. H. (1981) A new macrosystem for the Phylum Ciliophora Doflein, 1901. BioSystems 14: 387-401

Stein F. (1863) Auf der Reise in die Ostsee bei Wismar beobachtete neue oder noch nicht genügend bekannte Infusorienformen. Amtl. Ber. Ver. Dt. Naturf. Ärzte Karlsbad 37: 161-162, 165 166

Stokes A. C. (1890) Notices of new fresh-water infusoria. Proc. Am. Phil. Soc. 28: $74-80$
Strimmer K., von Haeseler A. (1997) Likelihood-mapping: a simple method to visualize phylogenetic content of a sequence alignment. Proc. Natl. Acad. Sci. USA 94: 6815-6819

Strüder-Kypke M. C., Wright A.-D. G., Foissner W., Chatzinotas A., Lynn D. H. (2006) Molecular phylogeny of litostome ciliates (Ciliophora, Litostomatea) with emphasis on free-living haptorian genera. Protist 157: 261-278

Sun P., Clamp J. C., Xu D. (2010) Analysis of the secondary structure of ITS transcripts in peritrich ciliates (Ciliophora, Oligohymenophorea): implications for structural evolution and phylogenetic reconstruction. Mol. Phylogenet. Evol. 56: 242-251

Sun P., Clamp J. C., Xu D., Huang B., Shin M. K., Turner F. (2013) An ITS-based phylogenetic framework for the genus Vorticel$l a$ : finding the molecular and morphological gaps in a taxonomically difficult group. Proc. R. Soc. B 280: 20131177

van Nues R. W., Rientjes J. M., van der Sande C. A., Zerp S. F., Sluiter C., Venema J., Planta R. J., Raué H. A. (1994) Separate structural elements within internal transcribed spacer 1 of Saccharomyces cerevisiae precursor ribosomal RNA direct the formation of 17S and 26S rRNA. Nucleic Acids Res. 22: 912-919

Vd'ačný P. (2017) Integrative taxonomy of ciliates: Assessment of molecular phylogenetic content and morphological homology testing. Eur. J. Protistol. 61: 388-398

Vd’ačný P., Foissner W. (2009) Ontogenesis of Dileptus terrenus and Pseudomonilicaryon brachyproboscis (Ciliophora, Haptoria). J. Eukaryot. Microbiol. 56: 232-243

Vd'ačný P., Foissner W. (2012) Monograph of the dileptids (Protista, Ciliophora, Rhynchostomatia). Denisia 31: 1-529

Vd'ačný P., Foissner W. (2013) Synergistic effects of combining morphological and molecular data in resolving the phylogenetic position of Semispathidium (Ciliophora, Haptoria), with description of $S$. breviarmatum sp. n. from tropical Africa. Zool. Scr. 42: 529-549

Vd’ačný P., Rajter L'. (2015) Reconciling morphological and molecular classification of predatory ciliates: evolutionary taxonomy of dileptids (Ciliophora, Litostomatea, Rhynchostomatia). Mol. Phylogenet. Evol. 90: 112-128

Vd'ačný P., Rataj M. (2017) Evaluation of systematic position of helicoprorodontids and chaeneids (Ciliophora, Litostomatea): an attempt to break long branches in 18S rRNA gene phylogenies. J. Eukaryot. Microbiol. 64: 608-621

Vd'ačný P., Orsi W., Foissner W. (2010) Molecular and morphological evidence for a sister group relationship of the classes Armophorea and Litostomatea (Ciliophora, Intramacronucleata, Lamellicorticata infraphyl. nov.), with an account on basal haptorid litostomateans. Eur. J. Protistol. 46: 298-309

Vd'ačný P., Bourland W. A., Orsi W., Epstein S. S., Foissner W. (2011a) Phylogeny and classification of the Litostomatea (Protista, Ciliophora), with emphasis on free-living taxa and the 18S rRNA gene. Mol. Phylogenet. Evol. 59: 510-522

Vd'ačný P., Orsi W., Bourland W. A., Shimano S., Epstein S. S., Foissner W. (2011b) Morphological and molecular phylogeny of dileptids: resolution at the base of the class Litostomatea (Ciliophora, Intramacronucleata). Eur. J. Protistol. 47: 295-313

Vd'ačný P., Bourland W. A., Orsi W., Epstein S. S., Foissner W. (2012) Genealogical analyses of multiple loci of litostomatean ciliates (Protista, Ciliophora, Litostomatea). Mol. Phylogenet. Evol. 65: 397-411

Vd’ačný P., Breiner H.-W., Yashchenko V., Dunthorn M., Stoeck T., Foissner W. (2014) The chaos prevails: molecular phylogeny of the Haptoria (Ciliophora, Litostomatea). Protist 165: 93-111 
Vd’ačný P., Rajter L., Shazib S. U. A, Jang S. W., Kim J. H., Shin M. K. (2015) Reconstruction of evolutionary history of pleurostomatid ciliates (Ciliophora, Litostomatea, Haptoria): interplay of morphology and molecules. Acta Protozool. 54: 9-29

Vd'ačný P., Rajter L', Shazib S. U. A, Jang S. W., Shin M. K. (2017) Diversification dynamics of rhynchostomatian ciliates: the impact of seven intrinsic traits on speciation and extinction in a microbial group. Sci. Rep. 7: 9918

Weisse T., Strüder-Kypke M. C., Berger H., Foissner W. (2008) Genetic, morphological, and ecological diversity of spatially separated clones of Meseres corlissi Petz \& Foissner, 1992 (Ciliophora, Spirotrichea). J. Eukaryot. Microbiol. 55: 257-270

Wolf M., Achtziger M. C., Schultz J., Dandekar T., Müller T. (2005) Homology modeling revealed more than 20,000 rRNA internal transcribed spacer 2 (ITS2) secondary structures. RNA 11: 1616-1623

Wu L., Clamp J. C., Yi Z., Li J., Lin X. (2015) Phylogenetic and taxonomic revision of an enigmatic group of haptorian ciliates, with establishment of the Kentrophyllidae fam. n. (Protozoa, Ciliophora, Litostomatea, Pleurostomatida). PLoS One 10: e0123720
Wu L., Jiao X., Shen Z., Yi Z., Li J., Warren A., Lin X. (2016) New taxa refresh the phylogeny and classification of pleurostomatid ciliates (Ciliophora, Litostomatea). Zool. Scr. 46: 245-253

Yi Z., Chen Z., Warren A., Roberts D., Al-Rasheid K. A. S., Miao M., Gao S., Shao C., Song W. (2008) Molecular phylogeny of Pseudokeronopsis (Protozoa, Ciliophora, Urostylida), with reconsideration of three closely related species at inter- and intraspecific levels inferred from the small subunit ribosomal RNA gene and the ITS1-5.8S-ITS2 region sequences. J. Zool. 275: 268-275

Zhang Q., Simpson A., Song W. (2012) Insights into the phylogeny of systematically controversial haptorian ciliates (Ciliophora, Litostomatea) based on multigene analyses. Proc. R. Soc. Lond. B Biol. Sci. 279: 2625-2635

Zuker M. (2003) Mfold web server for nucleic acid folding and hybridization prediction. Nucleic Acids Res. 31: 3406-3415

Received on $11^{\text {th }}$ August, 2017; revised on $31^{\text {st }}$ October, 2017; accepted on $2^{\text {nd }}$ November, 2017 


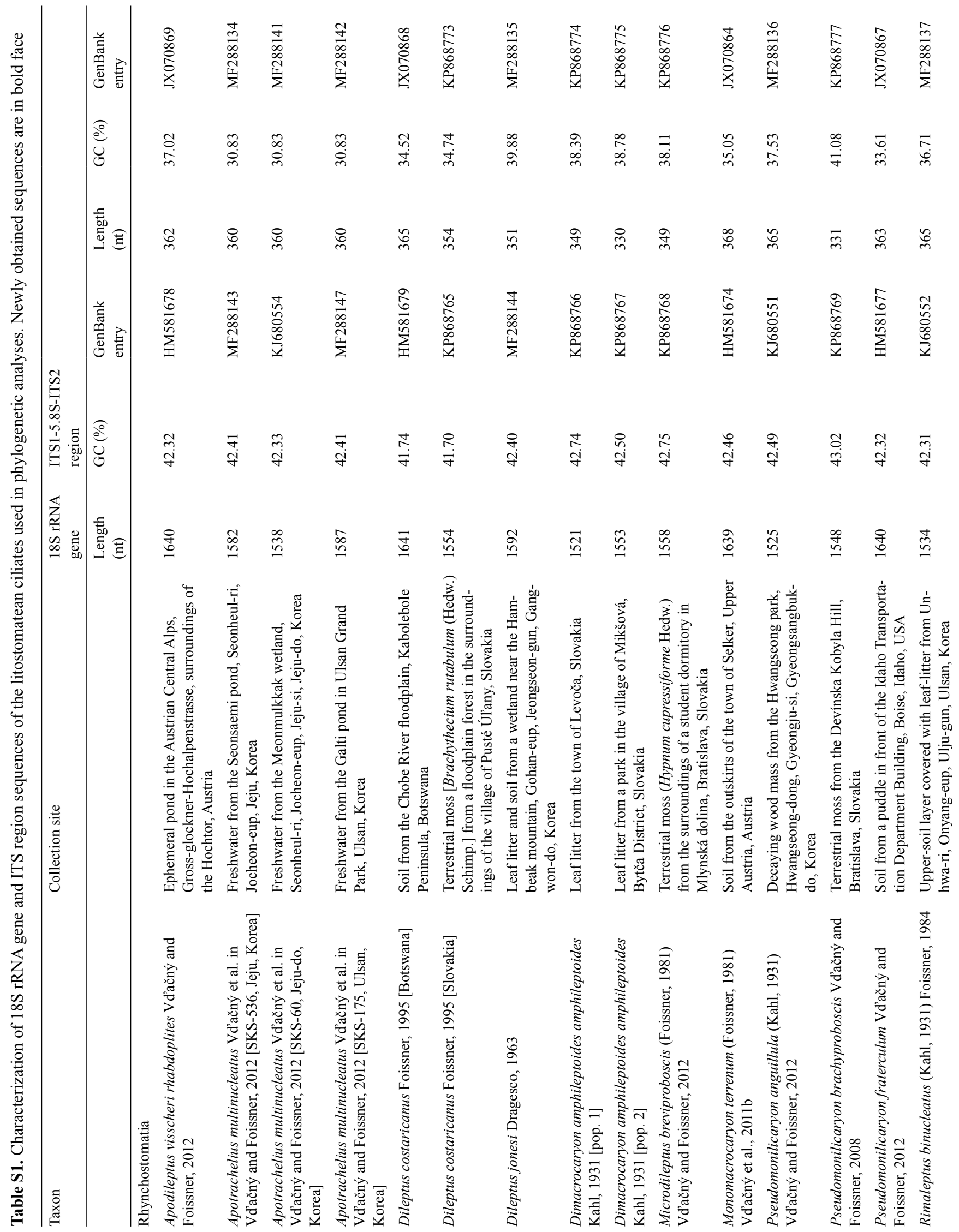




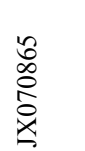

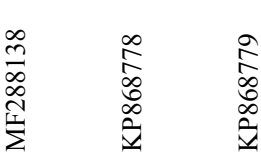

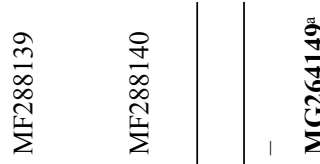

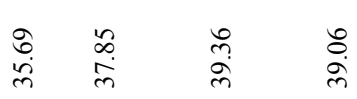

i

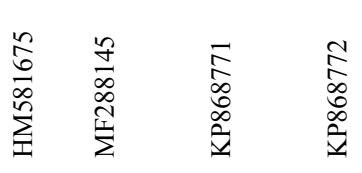

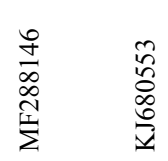

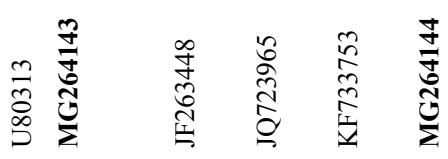

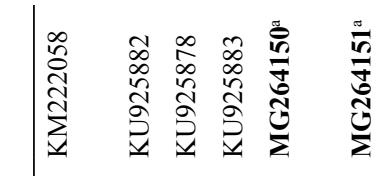

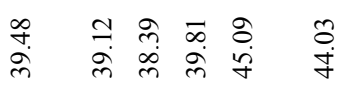

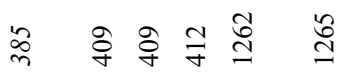

ָे

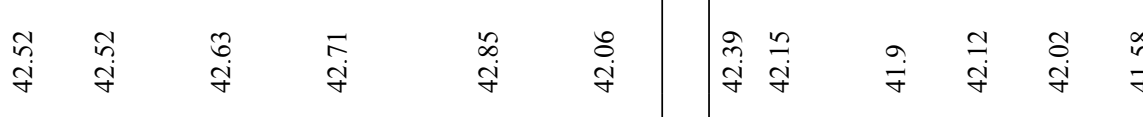

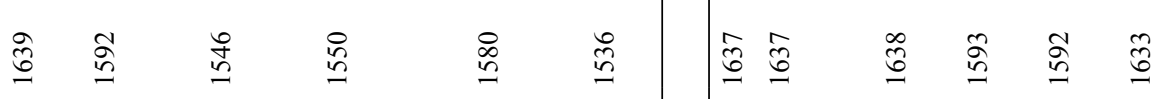

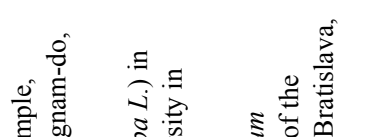

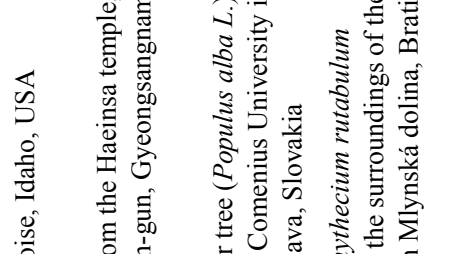

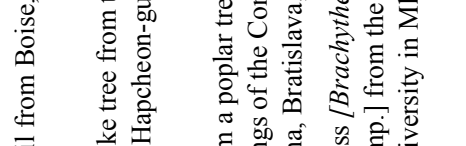

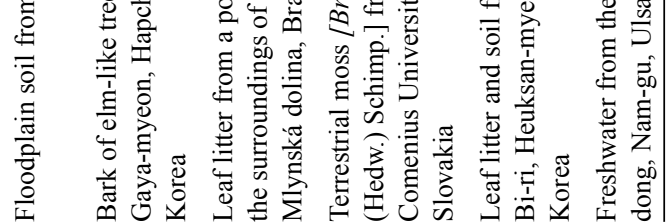

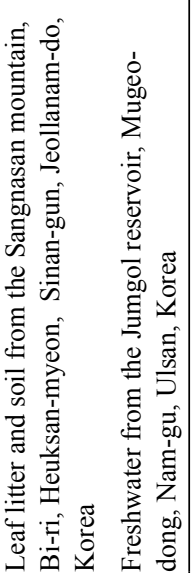

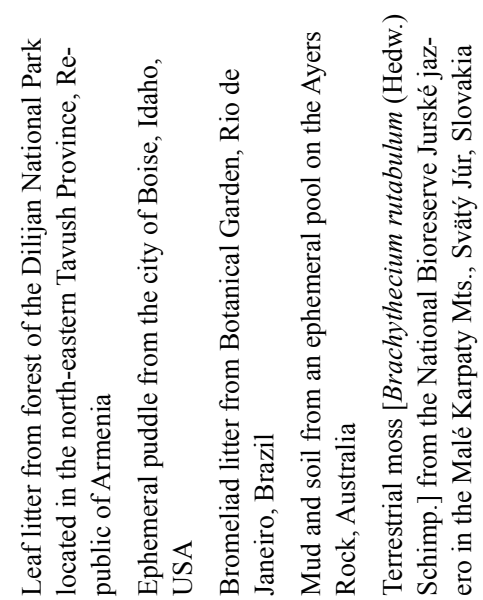

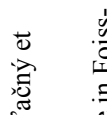

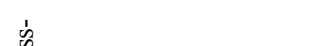

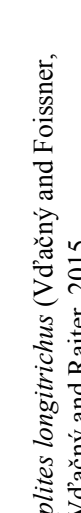

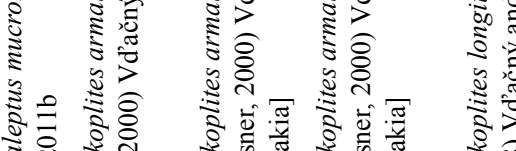

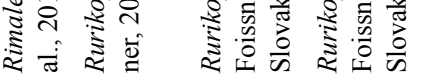

霓

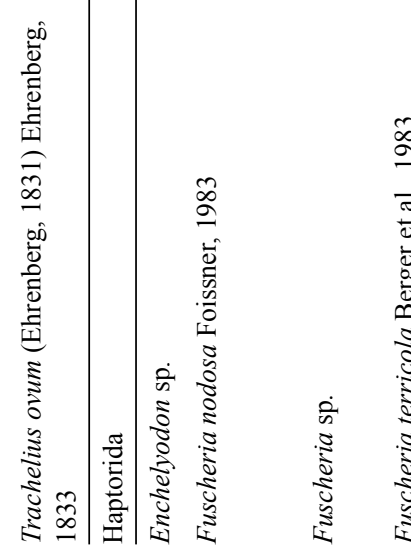

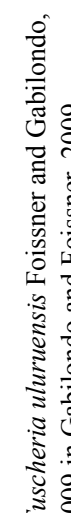
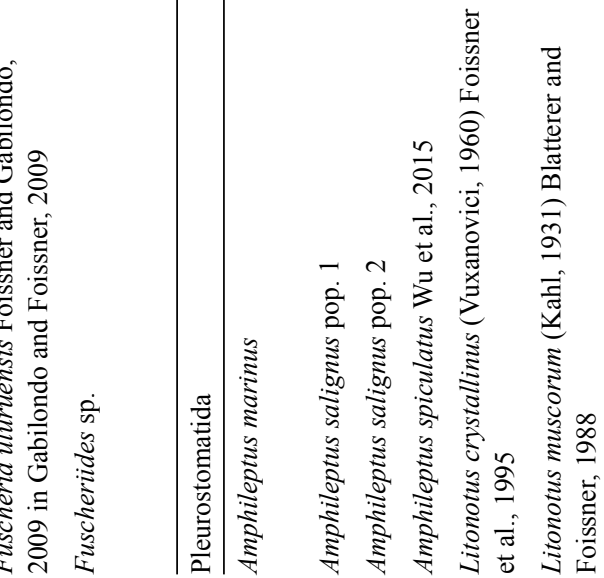


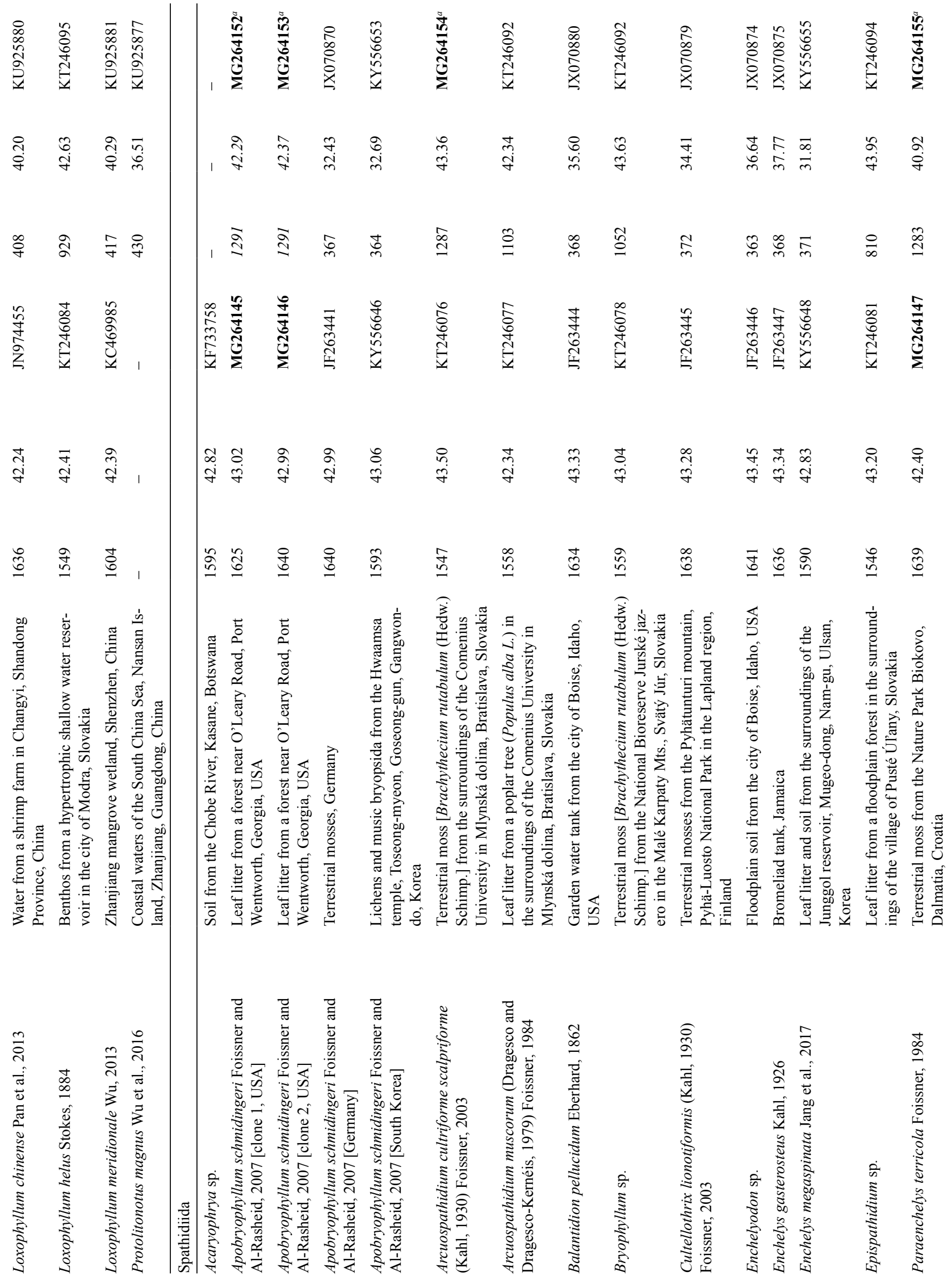




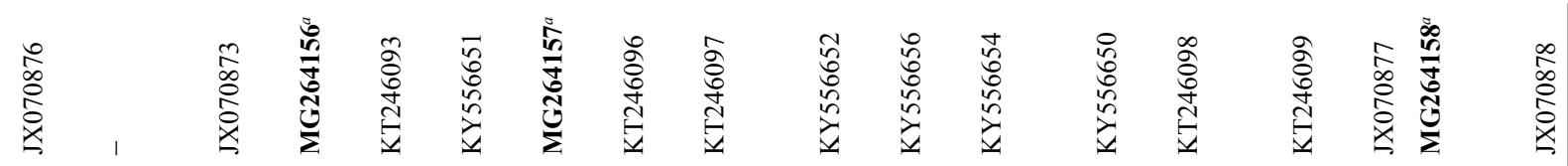

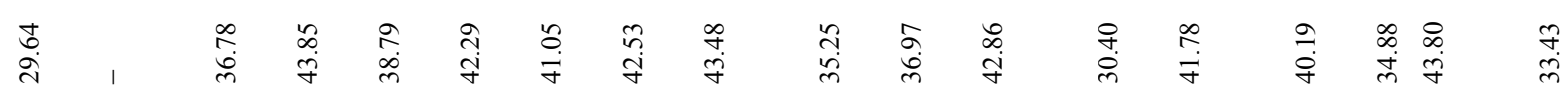

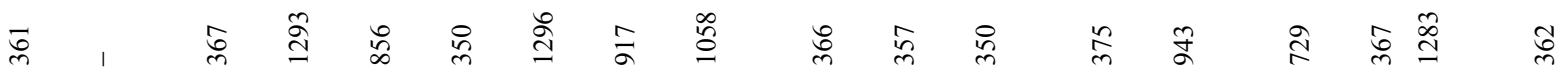

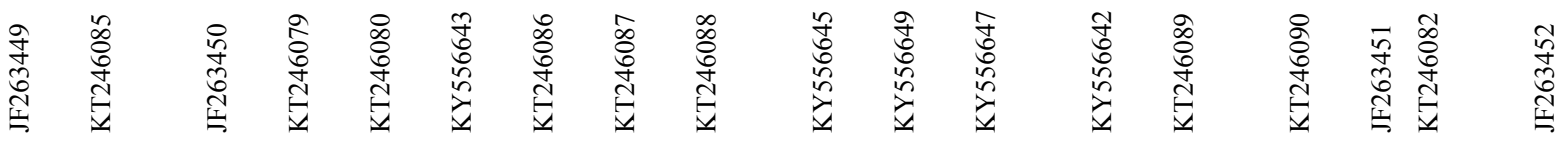

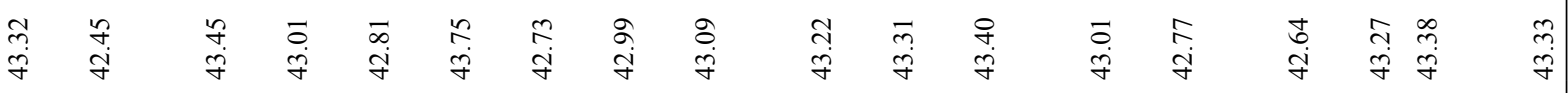

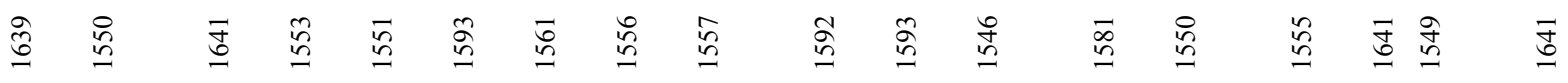

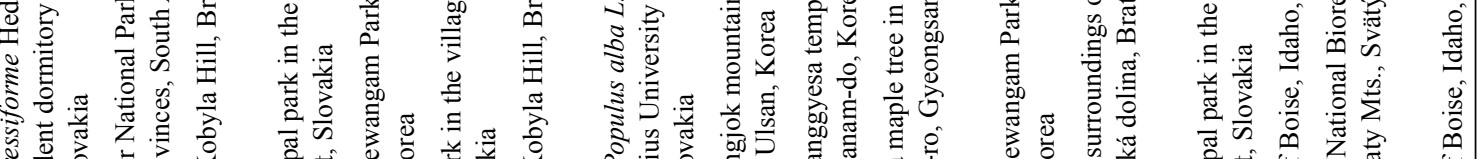

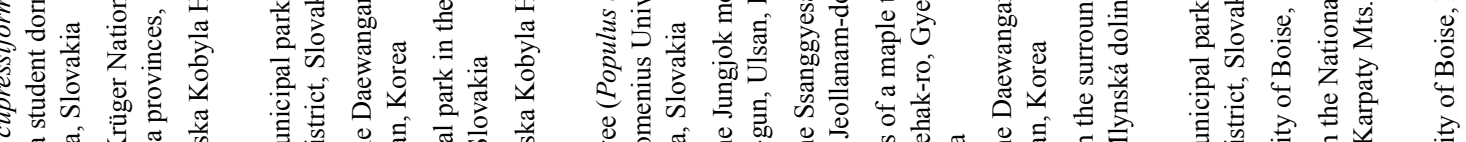

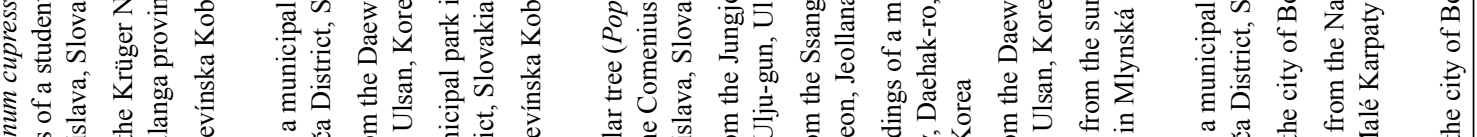

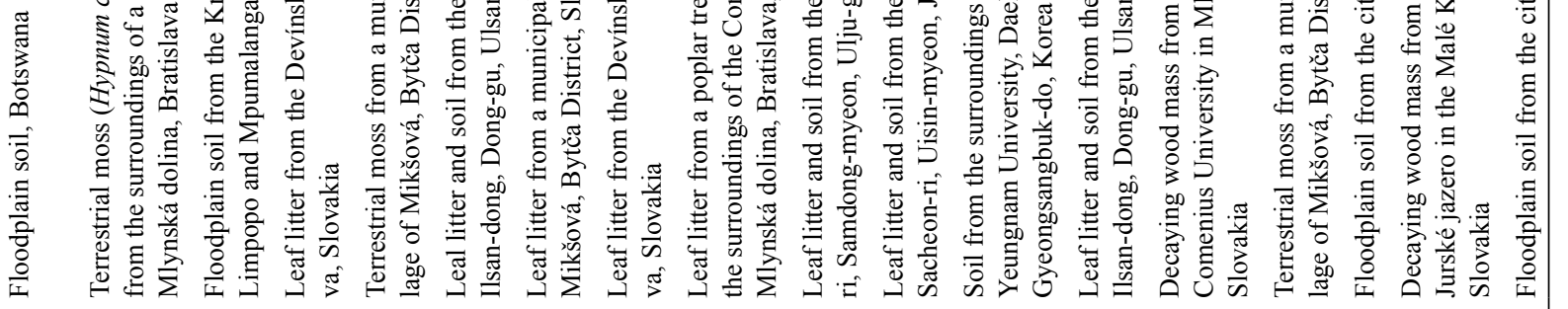

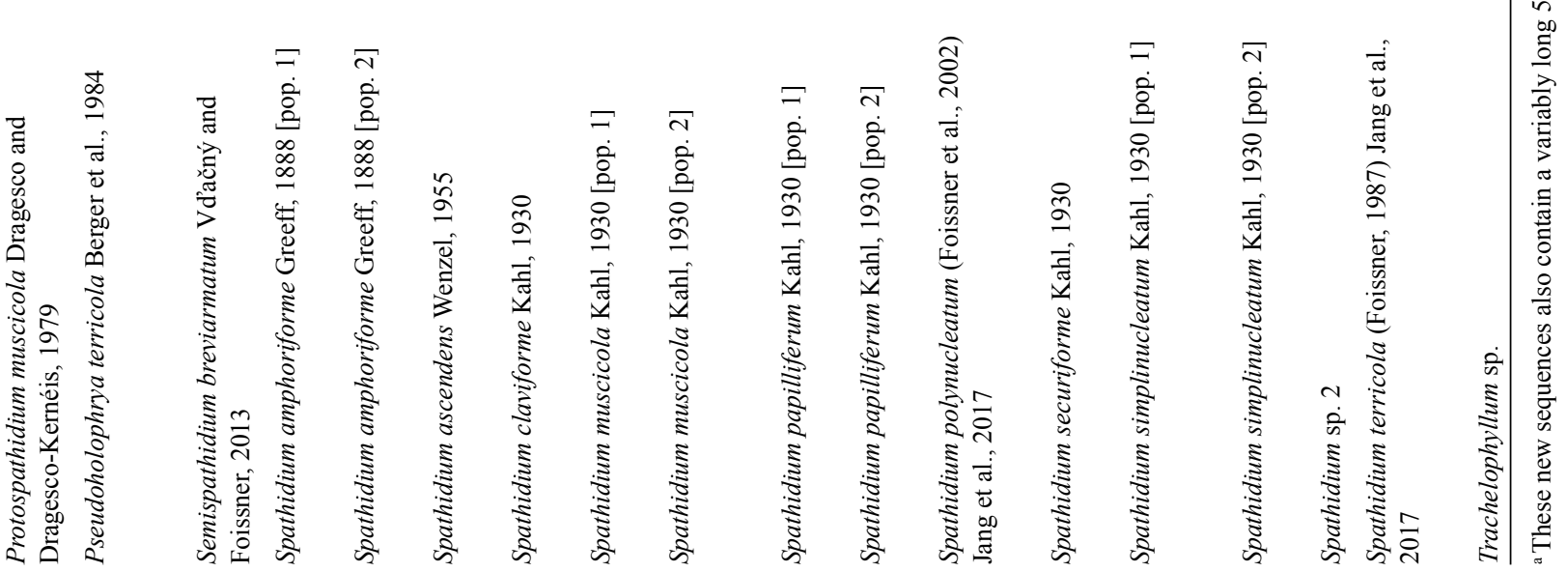




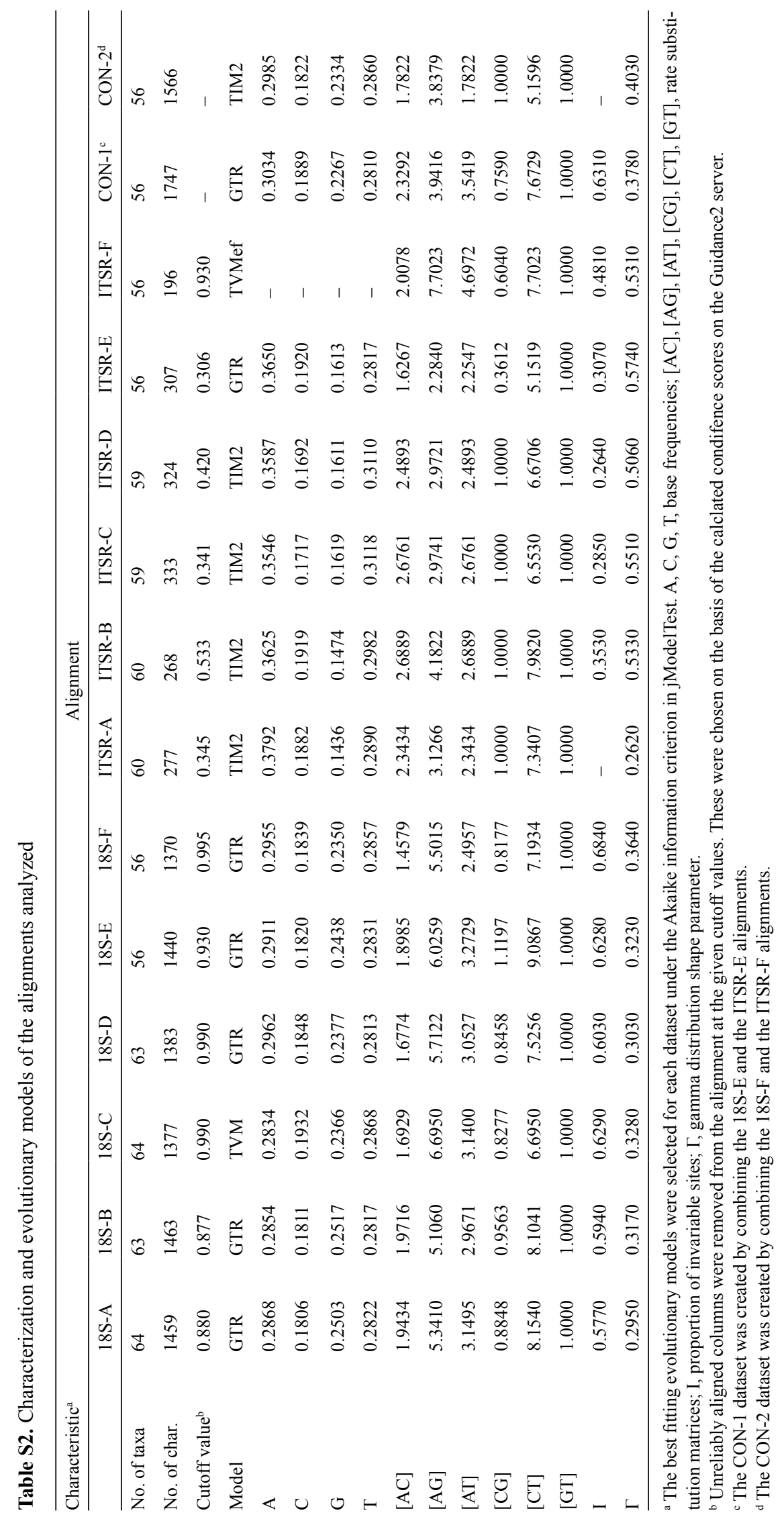

